POLIICALECONOMY RESARCHINSTIUIE

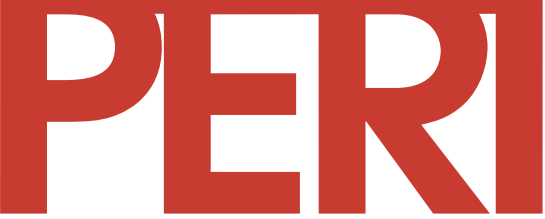

University of Massac husetts Amherst

\title{
Development in A Time of Globalization
}

\author{
J . Mohan Rao
}

1998

10th floor Thompson Hall

University of Massachusetts

Amherst, MA, 01003-7510

Telephone: (413) 545-6355

Facsimile: (413) 545-2921

Emailperi@ec onsumassedu Website:

htp:// www.umassedu/peit/

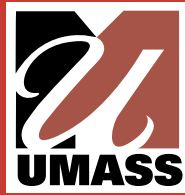




\title{
Development in the Time of Globalization
}

\author{
J. Mohan Rao* \\ University of Massachusetts at Amherst
}

Revised: February 1998

[First Draft: October 1997]

Paper prepared for the Workshop on Globalization, Uneven Development and Poverty, UNDP, New York, October 24-25, 1997.

* I I thank Terry McKinley and the UNDP for providing support and Barsha Khattry of the University of Massachusetts for excellent research assistance. Comments from and discussions with participants at the New York conference on Globalization, Uneven Development and Poverty, October 1997, are gratefully acknowledged. I alone am responsible for the views expressed in this study. 


\begin{abstract}
The paper examines grounds on which a 'second opinion' to the Washington Consensus may be constructed using data for a sample of 123 rich and poor nations for the period from 1960 to 1995. The historical record makes abundantly clear that international inequality has increased not only over the long haul of the past two centuries but also in recent decades. Unequal development derives mainly from economic and political-economic forces internal to nations. Unregulated global market forces mostly follow this process rather than countering it. At the same time, the fragile internal development process is vulnerable to the disruptive forces of unrestricted openness. To be sure, access to global markets can be a powerful factor in development. But development success has hinged on selective and phased integration with world markets. This understanding clearly goes against the prevailing view that the growth benefits from globalization far outweigh the costs and that the main task for developing countries is to eliminate all impediments in the way of integrating their domestic economies with global trade and financial flows.

It is not only economic growth as it relates to globalization that is at issue. The historical record also shows that the wealth of nations alone fails to account for variations in the levels of national poverty and inequality. Hence, we must also be concerned about whether increasing globalization restructures incentives in a direction that is conducive to reducing inequality and poverty. Apart from the purely economic mechanisms, this concern must extend also to the capacities for public action that globalization might weaken. The paper is animated by the belief that given the continuing primacy of the nation state, a modicum of national policy autonomy is vital to a politically sustainable economy, particularly in redressing endemic problems of poverty and inequality.
\end{abstract}




\section{INTRODUCTION}

International flows of goods and of finance capital have doubtless increased sharply over the last few decades. Non-traditional manufacturing exports from the newly industrializing countries (NICs) of Asia to the developed have scaled new heights. The rapid growth of national incomes in China, Malaysia, Thailand and Indonesia has been accompanied by an accelerated expansion of foreign direct investments (FDI) from outside and within the region, especially Japan, Hong Kong, South Korea and Singapore.

Some have heralded a new era of globalization marked by rapidly growing world trade and capital movements. Others argue, however, that the world economy is actually less integrated today than it was in the late 19th century (see for example Rodrik, 1997). But such comparisons invite further scrutiny. It is true that labor movements, in the form of mass migrations from the old world to the new, were substantially higher during the 19th century than they are today. Similarly, net capital outflow relative to GNP was much higher in the UK prior to World War I than at any time since. But a large share of these labor and capital flows was restricted to the same group of countries which today account for the lion's share of goods flows. The significance of capital and labor movements in such a comparison cannot be considered apart from trade flows. Economies may be 'integrated' by goods flows even in the absence of any factor movements. Turning to trade volumes relative to national incomes, measured openness in the US and in Europe peaked before World War I, fell sharply between the wars and trended upward after World War II. By this measure, the advanced economies of the world are not any more open in 1997 than they were in 1897. But per capita incomes in these advanced economies are many times larger today and, as a result, the share of services, which tend to be far more non-tradable than goods, is considerably higher. Hence, even constant trade ratios 
represent a significant increase in openness.

A rather more compelling argument against the liberal use of the term globalization is that the movement of goods, capital and enterprises across national boundaries is marked by great unevenness. First, developed nations, whether as sources or as destinations, account for a disproportionate share of these flows relative to their share in global income. Second, even as tariff barriers have declined, old forms of non-tariff restraints on trade persist while new ones are coming into vogue. Third, the formal and informal creation of regional blocks for trading and investment may be seen as a threat to the forces of integration across these blocks and, even more, as a factor further isolating the numerous countries and regions in the South that do not enjoy political or economic proximity with Japan, the US or the EU. Finally, there remain great asymmetries in the stability and composition of exports as between the developed nations and NICs on the one hand and the less developed countries (LDCs) on the other.

On the whole, the balance of forces seems to point in the direction of globalization at least in the descriptive sense of a process increasing international resource and goods flows. Apart from the information and communication revolutions that have reduced the costs of international transactions, the impetus for these flows has come from changing policy regimes in both rich and poor countries. Formal processes of market integration have been initiated in North America and are reaching their culmination in western Europe. The GATT/WTO framework will phase out important areas of managed trade and protectionist policy. Many among the less developed countries of the third world and the second have shifted policies, in 
some cases radically, towards opening up their economies to global markets ${ }^{1}$.

To some extent, the nature of policy changes has been conditioned by changing economic circumstances and institutions. All the same, the role of national and international policy deliberation (together with the powerful influence of politics and ideology that that implies) should not be underestimated whether in rich or poor nations. Consider the advanced countries first. Though the unraveling of the monetary arrangements of the post-War era in 1971, the productivity growth deceleration starting in the late 1960s and the oil price increase of 1973 had a definite impact on the shape of international economic relations during the succeding decades, these are themselves best seen as following from the crumbling of the particular politicaleconomic regime (termed Fordism) that maintained stable national and international regimes of rapid growth (the Golden Age) ${ }^{2}$. The convergence of productivity and income levels in Europe and Japan to those prevalent in the US accelerated the growth of intra-industry trade and investments among these regions. Protectionist barriers to trade also came down in successive rounds. In other words, converging incomes produced market integration, not only the other way around.

By the same token, however, the maintenance of export competitiveness began to emerge as a new imperative rivaling the Fordist concerns about maintaining real wage growth and the

${ }^{1}$ Some use the term globalization to denote policy changes intended to bring about increased global integration. Past experience shows that there is no necessary or one-to-one connection between such policy changes and the actual extent of integration. It is therefore best to restrict the term globalization to indicators of actual integration while liberal policy moves on the external front may be denoted by "external liberalization".

${ }^{2}$ Recent accounts of the constituents of the Fordist Golden Age and of the paths out of that regime of accumulation are given in Boyer (1995) and Lipietz (1995). 
welfare state. The new imperative arose at the same time that the internal growth potential of Fordism was petering out. Attempts at fine-tuning the economy led to structural inflation and external imbalance and, in response, businesses demanded fiscal and labor discipline (Cox, 1994). Inflation control on the macro side and all-around 'flexibility', including deregulation, on the supply side became the hallmarks of new conservative policy regimes. Assaults on the welfare state, more or less extensive, have followed in their wake. But the very diversity of policy responses across countries underscores the role of politics.

The LDCs as a group and individually enjoyed respectable rates of economic growth during the Golden Age which surpassed their dismal performance during the colonial era. This difference was not simply due to the global economic environment of the Golden Age alone; rather, a large if variable share of the difference must be accounted for by the transition from colonialism to sovereignty and the developmental role of the state. The growth momentum was maintained even through the 1970s in part because of better export prices for many raw material exports and the recycling of petro-dollars. But the eventual crash in the early 1980s, brought on by the crushing rise in interest rates and the sharp adverse movement in the terms of trade, turned out to be far more costly in the South, particularly in Sub-Saharan Africa and Latin America, than the earlier one had been in the North. Straitened fiscs (reflecting the internal transfer problem arising from the debt crisis) undermined state capacities to pursue indigenous models of modernization or to sustain and expand anti-poverty programs, prompting or necessitating a shift in regimes.

Conditionalities imposed by international creditors, in the form of orthodox stabilization and structural adjustment programs, have been a major instrument for opening up these 
economies to the winds of global competition. Over the decade and a half since the ReaganVolcker recession and the Mexican debt crisis that followed, the developing world has witnessed a remarkable convergence in official economic policy thinking and in policy regimes. The hard core of these widely espoused policies, sometimes termed the Washington Consensus, may be accurately described as the neo-liberal nostrum of the laissez-faire market. Neo-liberalism augments the traditional liberal belief in conservative macroeconomic policy and unregulated markets with the dictum that the state can do little right if only because it is liable to be captured by special interests. Conversely, the market can do no wrong so long as the political process can be reined in. Political discipline is best secured by integrating the domestic market completely with global markets ${ }^{3}$. An economy significantly sheltered from world markets always affords a measure of policy autonomy. But then, like nature's abhorrence of a vacuum, economic subversion through political means must ensue. Hence, the neo-liberal prescription coupling internal liberalization and external market integration ${ }^{4}$.

But apart from this purely negative argument of the need to discipline the state (with the market providing the means), the neo-liberal view is equally founded on the old argument that free markets optimize national welfare. This central tenet is anchored in five basic assumptions: 1) that a politically unconstrained market regime is feasible (distributional problems can be resolved, if they must be, without `distorting' the market); 2) that the market can fully coordinate

${ }^{3}$ Srinivasan (1986) provides a lucid overview though debatable defence of what has come to be called neoclassical political economy.

4 This line of thinking implies that an existing regime of protection will be difficult to dislodge: shelters provide policy autonomy which will be obligingly used to perpetuate the shelters. For the same reason, however, a neo-liberal regime, once instituted, will go on unmolested. 
individual decisions e.g., produce full employment (the state can only get in the way); 3) that public investment is an inefficient substitute for private investment in the growth process (complementarities are negligible); 4) that the unhindered import of technology can provide an adequate basis for developing competitiveness (a level playing field imposes no handicaps in building up dynamic competitive advantage); and 5) that the free movement of finance and enterprises across the national border will produce internal and external balance (globalization is good for the South) ${ }^{5}$.

In fact, the neo-liberal diagnosis and prescription have a timeless and spaceless character to them: they are supposed to apply with equal force to both rich and poor countries, North and South, early and late industrializers. Liberal policies and openness are predicted to be a guarantee of global economic integration and of convergence in national living standards - the creation of a global economic system. Existing inequalities among or within nations pose no impediments to any of them deriving these benefits; nor do such inequalities justify anything other than the neo-liberal prescriptions.

Despite the air of ineluctability that the term Washington Consensus applied to this agenda conveys, alternative viewpoints or second and third opinions are scarcely lacking. Some predate the neo-liberal ascent, others are direct responses to the current phase of globalization. While some offer alternative means to development, others also question the very ends of development accepted in the mainstream.

${ }^{5}$ Characteristically, these benefits are supposed to diffuse widely among the population while the benefits of illiberal policies are supposed to be highly concentrated. But if diffuse beneficiaries are apt to be "rationally" apathetic to politics, as this literature typically maintains, it is hard to see how a neo-liberal regime might ever get going. 
First, there is 'traditional' development economics the main thrust of which has been the analysis of the structural determinants of low incomes and productivity and the means by which they might be overcome. Capital market failures, the indivisibility of infrastructural investments and problems of investment coordination have been especially emphasized. Many of the structural determinants (such as low saving rates and low agricultural productivity) are themselves related to low incomes or to institutional impediments and asset inequalities. Hence, their self-perpetuating tendencies are seen to require proactive public interventions and policies. Confronted with two centuries of increasing inequalities among nations (which included significant periods of wide-open national economic borders), both early development economists and theorists of dependency and underdevelopment argued that the inherited international division of labor is part of the problem, not part of the solution (Prebisch, 1959 and Frank, 1966). The policy approach emphasizes accumulation, industrialization and mobilization of labor resources and presupposes a key strategic and coordinating role of the state. Although this approach has of course been refined in the light of experience and refashioned for a changing world, its basic insights remain undiminished in importance.

Second, one direction in which development theory has been reformulated is to incorporate what may be described as the influence of world time. This follows the lead of Gerschenkron (1959) who argued that in an unequal world, international demonstration effects tend to produce successive paths of development different from earlier ones. Gerschenkron did not deny the relevance of structural "preconditions" for modern economic growth but showed historically that late developers had sought institutional substitutions to meet these requirements. It seems clear that late-industrializing countries can secure the advantage of lateness (consisting 
in not having to reinvent the technological wheel) only by creating an appropriate infrastructural, informational and incentive base for local learning and development (Amsden, Kochanowicz and Taylor $)^{6}$. The contrast between the experience of the East Asian countries and much of the rest of the third world demonstrates little if not this basic lesson. While it is equally clear that such a course requires delicate management and a strong state, it makes no sense to take a mechanistic view of either markets or politics which forecloses (or renders inevitable) such adaptive response ${ }^{7}$.

Third, another "new" direction in development theory goes further than the pioneers of development economics in emphasizing the role of increasing returns in economic activity. Rosenstein-Rodan had emphasized the role of investment indivisibilities and externalities in producing market failures in backward economies. Following Smith and Young, Myrdal and Kaldor had similarly made increasing returns an important part of their theories of economic growth. The "new" growth theory (Romer, 1986 and Lucas, 1987) pursues this idea within a neoclassical methodological framework that emphasizes the role of learning based on human capital accumulation and knowledge spillovers across firms and sectors. Whereas early development theories spoke in terms of a low-level poverty equilibrium and ways of getting out of it, the new growth theory describes a moving equilibrium of rising relative poverty. Viewed purely mechanistically, increasing returns imply unbounded divergence and capital movements in the 'wrong' direction: high productivity nations enjoy faster rates of productivity increase and

${ }^{6}$ Indeed, the very distinction between active technical invention and passive diffusion has had to be modified in the light of historical experience showing that the mere transfer or imitation of technologies does not realize the potential gains.

${ }^{7}$ This admonition applies as well to the neo-liberal position. See footnotes 3 and 4. 
accumulation. The bare facts of divergent growth have been used to support the applicability of these theories.

Fourth, there is an emerging view that globalization poses a tradeoff between the flexibility of resource allocation that it ensures and the uncertainty of incomes, occupations and ways of life it generates ${ }^{8}$. The uncertainty entails increasing state expenditures on the welfare state and social insurance. But these interventions can neither be entirely efficacious nor fiscally sustainable in a globalized world. If not adequately preempted, the argument goes, a reaction is likely to set in which may undermine the basis of a globalized economy. It is probably fair to say that this view, unlike the preceding alternatives, accepts the neo-liberal proposition that globalization increases resource efficiency and growth for all countries. Rather, it is troubled by the clipping of national autonomy that neo-liberals take to be a central virtue of globalization.

Finally, the preceding view finds a deeper and more extended statement in cultural theories of economic development and of politics ${ }^{9}$. For the most part, economists have been content with seeing technology and unchanging preferences as the bedrock on which economic growth rests. Pushed to their logical conclusions, both structural and neoclassical economic theories arrive at mechanistic cul-de-sacs. For one, economistic theories ignore the specific political and cultural histories of diverse regions and the ways in which they may shape economic possibilities. For another, the same histories may also define a heterogeneity of beliefs and values not only across but also within individual societies. Not all societies can be presumed to

${ }^{8}$ See Rodrik (1996) for an elaboration of this viewpoint.

9 See, for example, the report of the World Commission on Culture and Development (1995), Greider (1993), Barber (1997) and Rao (1997). 
be playing the same "game" and with the same expectations. But for the same reasons, there is a danger of ignoring the role of human creativity in producing new possibilities (whether for better or for worse).

Our aim in this paper is to explore the grounds on which a `second opinion' to the Washington Consensus may be constructed. Several of the themes outline above are pursued further with preliminary and partial empirical investigations covering the period from 1960 to 1995 and a large sample of 123 rich and poor nations. The historical record makes abundantly clear that international inequality has increased not only over the long haul of the past two centuries but also in recent decades. The self-reinforcing power of unequal development derives mainly from economic and political-economic forces internal to nations. Unregulated global market forces mostly follow this process rather than countering it chiefly because they reinforce inherited resource endowments and the inherited division of labor. At the same time, the fragile internal development process is vulnerable to the disruptive forces of unrestricted openness. To be sure, access to global markets can be a powerful factor in development. But development success in the post-War era has hinged on selective and phased integration with world markets.

This understanding clearly goes against the prevailing view that the economic growth benefits from globalization far outweigh the costs and that the main task for developing countries is to jump on the global bandwagon by eliminating all impediments in the way of integrating their domestic economies with global trade and financial flows. But it is not only economic growth as it relates to globalization that is at issue. The historical record also shows that the wealth of nations alone fails to account for variations in the levels of national poverty and inequality. Hence, we must also be concerned about whether increasing globalization 
restructures incentives in a direction that is conducive to reducing inequality and poverty. Apart from the purely economic mechanisms, this concern must extend also to the capacities for public action that globalization might weaken. The paper is animated by the belief that given the continuing primacy of the nation state, a modicum of national policy autonomy is vital to a politically sustainable economy, particularly in redressing endemic problems of poverty and inequality.

The paper is structured as follows. Section 2 presents the results of cross-country analysis showing increasing international income inequality during the whole period as well as during 1960-78 (which was part of the Golden Age) and 1979-92 (which includes the troubled decade of the 1980s) together with a critical perspective on the so-called convergence debate. In section 3 , the strength of international integration is assessed both empirically and theoretically mainly from the perspective of LDCs. Contrary to the Law of One Price, growing international inequality has been accompanied by internationally divergent price structures. Theoretical arguments about the gains from trade are then evaluated with this and other evidence. Section 4 argues that LDC financial markets are fragmented internally and poorly integrated externally. Global flows of finance are highly concentrated across countries and account for less than 5\% of global investment. In addition, cross-country analysis for recent years shows that capital flows are positively related to per capita income: if we suppose that in a properly functioning market, capital 'would' flow from capital-abundant to capital-scarce regions, then, this result certainly suggests a poorly functioning market. We then outline some of the difficulties that LDCs must confront if they choose to reorder their financial and fiscal systems to attract foreign capital. Section 5 examines cross-country differences in accumulation and industrialization, two key 
variables traditionally emphasized in development theory. Internationally comparable data show that investment rates are strongly related to per capita income levels. Similarly, we find that the positive relationship between industrialization and income levels is notably stronger when services are excluded in measuring the former. Cross-country comparisons also show that an economy's openness to trade and the composition of its trade are powerfully influenced by its income level. The theoretical arguments supporting the empirical patterns of structural change are also outlined. The final section spells out important areas where our understanding of late industrialization has advanced beyond traditional development theory and which can inform a renewed approach to development policy. But there also remain some key issues, especially those pertaining to the role of the state and governance, and to inequality, where current understanding remains limited.

\section{UNEVEN ECONOMIC GROWTH}

Massive increases in inequalities among nations during the era of modern economic growth do not inspire confidence in the liberal prediction or prescription. Living standards over much of the old world were proximately similar around 1600. Even as late as 1800, per capita income in Europe and North America was roughly the same as that prevalent in Asia (Schwartz,

1994). But by 1900 , incomes in the center were around 10 times as large as in the periphery and the gap had doubled again by 1960. Yet, markets in the periphery were largely open to world commerce (and to investments financed by the richer nations) for the century preceding World War II. Notably, however, most peripheral states lacked sovereignty and were subjected to 
colonial exploitation. India's per capita income, for example, precisely stagnated under the Crown-imposed policy of laissez faire and virtual free trade. By contrast, a strongly regulated import-substitution regime after independence served to more than double India's per capita income. Moreover, there were significant episodes of industrialization in countries like Brazil, Mexico and India during the Great Depression and World War II when the world economy had virtually ceased to be global.

More recent evidence also provides broad support for this picture of divergent economic growth notwithstanding the exceptional performance of the East Asian and (lately) South-East Asian countries. The convergence of per capita incomes across nations may be statistically tested by regressing period growth rates of income on start-of-period incomes. A negative (positive) coefficient on initial per capita income implies convergence (divergence). The exercise we report here is based on national income data for 123 countries adjusted for nominal exchange rate deviations from purchasing power parity. The period covered by the PennTable data source is 1960-1992. We examine convergence for the whole period and also separately for the subperiods 1960-78 (which was part of the Golden Age of high growth) and 1979-92 (which includes the decade lost to development in much of the third world) ${ }^{10}$.

Per capita income growth rates were calculated by fitting exponential trend equations for

10 See Summers and Heston (1991) for a description of the methodology of the International Comparisons Project (ICP) on which the PennTable is based. A possible objection to the use of ICP-based incomes is that since the method obtains weighted average international prices from national prices using the Stone-Geary weighting procedure, the use of these average prices risks incurring a cross-national Gerschenkron Effect i.e., overestimating income growth in the rich compared to the poor countries if quantities and prices are generally inversely related in the cross-section (see Nuxoll, 1994). In fact, however, Nuxoll found that growth rates at international prices were actually less than those at national prices for the poor, not rich, countries (though this relationship was not statistically significant). 
each country and period ${ }^{11}$. Table 1 classifies the countries for each period by both income growth (low, middle and high) and income level (low, middle and high) with countries arranged in ascending order of income growth in each group ${ }^{12}$. The Table shows that the number in the low-growth group greatly increased at the expense of the high-growth group between the two periods. Though the loss of growth momentum affected all income groups, it was particularly pronounced among the low-income and middle-income countries (especially in Africa and Latin America).

Table 2 presents the period-wise results of the convergence regressions for each country group taken separately and for the whole sample. Taking all countries together, the results show statistically significant growth divergence over the whole period and over each of the sub-periods with the forces of divergence being stronger during 1979-1992 than during 1960-78. Taking each income group separately, we find that there was income convergence within the highincome and middle-income groups over both periods (with a higher speed of convergence in the second period than the first). While the low-income group also converged 'within' during the first period, it showed no such tendency during the second (actually the coefficient of initial income is positive though not statistically significant).

11 We used the PennTable income variable RGDPCH rather than RGDP. The latter, with base prices in 1985, suffers from the Laspeyres fixed-base problem (as relative prices change, base year weights become less appropriate). RGDPCH, based on a chain index, has the merit that its growth rate for any period is based upon international prices most closely allied with the period.

${ }^{12}$ The computed growth rates are not reported in the Table. The country groups are defined as follows: (1) by growth rates the ranges are < 1\% (low growth), 1-3\% (medium growth) and $>3 \%$ (high growth); and (2) by level of 1995 per capita incomes at national prices, the ranges being $\leq \$ 765$ (low income), $\$ 765-9386$ (middle income) and $\geq \$ 9386$ (high income). The latter classification is based on World Bank (1997). 
The bald facts of world-wide income divergence reported above confirm, for the two periods (and income groups) taken separately, similar results found in other samples ${ }^{13}$. But the facts of divergence have met with varied responses in terms of a theory of convergence - a sort of convergence cacophony. In the conventional (Solow) model of economic growth with diminishing returns to labor and capital, growth and initial income are supposed to be negatively related for the following reason. Around a long-run steady state, a low initial capital/labor ratio (which is associated with a low level of per capita income) implies high returns to capital. A rise in saving follows leading to a transitory rise in the capital-labor ratio i.e., as the economy moves to the steady state, accumulation and income growth will be at a higher rate than their long-run level ${ }^{14}$.

So on the face of it, the divergence results contradict the neoclassical Solow model of growth. This prompted a search for alternative theories that could explain the seeming anomaly. According to Baumol, Nelson and Wolff (1994), convergence is indeed not universal: there may be a convergence club. Members of the club are those who have high enough initial human capital endowments to take advantage of modern technologies. Apart from the high-income countries, these tend to be countries of middling rather than low incomes. Convergence is to be expected in restricted samples only, not in the world at large.

Another alternative was the so-called "new" theories of growth based on diverse sources

${ }^{13}$ See for example Baumol (1986), Barro and Xavier Sala-i-Martin (1992) and Mankiw, Romer and Weil (1992).

${ }^{14}$ The argument may be reinforced through extension to an open economy. Free trade in goods and technologies and the international mobility of capital will hasten the speed of convergence. 
of increasing returns (Romer, 1986). Increasing returns to the scale of inputs may be due to such factors as knowledge spillovers across enterprises and sectors, learning by doing (related to the scale of output or its rate of growth), R\&D activity and related human capital, various agglomeration economies, etc. High initial incomes, in this view, proxy for high levels of accumulated skill or human capital and, therefore, high future growth. Low-income countries cannot get high returns to human capital because they cannot take advantage of knowledge spillovers, etc and will therefore grow more slowly. In short, divergence is a natural corollary of increasing returns. One difficulty with this argument, of course, is that divergence is not a fact of life among the advanced capitalist countries ${ }^{15}$.

Others, however, soon argued that the facts of divergence contradicted the Solow model only if the fundamentals of the economies being compared are indeed the same. The Solow model does not predict absolute convergence - a simple negative relation between growth and initial income as countries converge to identical long-run incomes. Its prediction is conditional upon the fundamentals which include consumption preferences of the population, technology levels and long-run population growth rates. Countries may differ in their long-run per capita income levels (governed by the fundamentals). However, each country is predicted to grow more rapidly the larger is the gap between its initial income level and its own long-run per capita

15 More generally, increasing returns may not hold without bound. One reason may be the transformation of economic structure (from agriculture to industry and then to services) which changes the scope of increasing returns. Another might be the slowing down of accumulation when wages rise and eat into profits. Technological leaders do sometimes lose their lead in particular industries. Entire economies may similarly change their relative positions. Moreover, changes in the system and organization of knowledge may change its tradability across enterprises or national frontiers. Laggard economies may also find wholly new ways of generating knowledge which produce a burst of convergent growth. 
income level. In other words, the model predicts relative or contingent convergence (Barro and Sala-i-Martin 1992). Long-run income levels may well be different i.e., absolute divergence may hold but the Solow model is not disproved if contingent convergence holds.

But how is one to test for "long-run" differences in income levels? Barro, Mankiw and others found support for contingent convergence by introducing current values of variables that, they believe, could predict countries' future incomes. In their view, this vindicated the Solow model and diminishing returns. These results also seem to halt the new growth theory in its tracks. If economies differ in their exogenously given fundamentals, this is sufficient to explain divergent long-run incomes. Absolute divergence is not then due to a process of increasing returns working on nondiverging fundamentals (Pritchett, 1996, p. 42). Growth differentials are exogenous, not endogenous. Pritchett suggests the following analogy:

Suppose we tried to explain people's weight gain with a model in which weight gains or losses are predicted based on one's weight last year and one's height. If an individual's weight fluctuates around a more or less stable level that depends on height, then one will find convergence of weight, conditional on height. People who are thinner than their long-term average will, on average, gain weight and those heavier will, on average lose weight. This does not imply that over time everyone will weigh the same. The distribution of weight across individuals will remain exactly the same, irrespective of the speed of "conditional weight convergence" ( $\mathrm{p} 43$ ).

This analogy works if we know people's heights (analogously countries' long-run income levels). But have we any more means to know the future possibilities of developing nations than the heights at maturity of growing babies? Besides, the predictor variables used in the contingent convergence equation - saving rate, the rate of growth of population, human capital stocks - are all known to be highly correlated with per capita incomes. Poor economies tend to have high rates of fertility, low human capital stocks, low rates of saving and investment. Indeed, 
traditional development theory starting from Kuznets used these relationships as the stylized facts of development without presuming anything about convergence/divergence across nations. But in terms of the contingent convergence hypothesis, this must imply systematically changing fundamentals. In short, the hypothesis of contingent convergence "explains" the low growth rates of poor nations in terms of the very features that characterize their poverty which is nothing but unalloyed divergence by another route.

The implications of the contingent convergence, convergence club and increasing returns hypotheses seem rather pessimistic from the viewpoint of the developing countries. The first two of these interpret divergence in terms of "permanent" differences across nations using a "closed" model of the economy. If one is prepared to entertain such an interpretation, then, the statistical tests used to support it seem quite redundant. The tests transparently fail to address the real content of the hypothesis which remains buried in the black box of so-called "fundamentals". The increasing returns hypothesis is not any less "closed" or pessimistic than the other two. But it relies on the accidents of history to tell a story of divergence that is at least amenable to deeper historical treatment which some may find more satisfying. None of these hypotheses seems to call for any amendments to the neo-liberal policy position. But that may be so only because they are not directly concerned with international relations, the subject of the next two sections.

\section{INTERNATIONAL INTEGRATION}

In many ways, international relations are at the heart of neo-liberal doctrine. Its predictions and prescriptions for economic development derive directly from orthodox trade 
theory. It understands globalization not merely as a process but as an end state: the creation of a

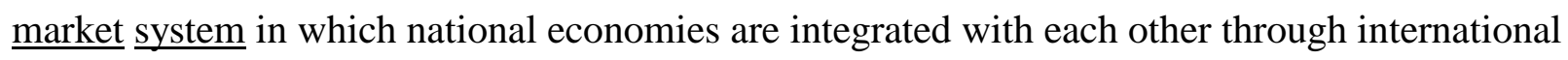
markets. Integration is identified with the establishment of the Law of One Price (or LOOP), the equalization of prices of both goods and factors. The achievement of allocative efficiency and the diffusion of technology are the bases for both absolute benefits and the equalization of productive powers across nations. Inequalities among nations pose no barriers to any of them deriving these benefits. On the contrary, LOOP under full integration (the integration of product and capital markets even without global labor mobility) implies equalization of factor prices and living standards across the globe. LOOP must hold in a self-regulating global market system in essentially the same way as it is supposed to hold within nations. In sum, globalization plus liberalization equals absolute convergence ${ }^{16}$. As Sachs and Warner (1995) put it:

"The world economy at the end of the twentieth century looks much like the world economy at the end of the nineteenth century. A global capitalist system is taking shape, drawing almost all regions of the world into arrangements of open trade and harmonized economic institutions. As in the nineteenth century, this new round of globalization promises to lead to economic convergence for the countries that join the system" (p.62-3).

By implication, the failure of convergence whether in the recent or distant past is to be accounted for by the failure of nations "to join the system". This prompts two related questions: (1) what are the mechanisms by which trade promotes development and are these weighty enough to warrant the neo-liberal position? (2) is the recalcitrance of nations to join the system adequate to explain the failure of convergence?

${ }^{16}$ Proponents of this world view generally do not allow their vision to be clouded by ideas about possibly divergent "fundamentals" across nations. Although factor price equalization does not amount to absolute convergence, it does imply convergence of "full incomes". 
First, consider the role of international relations in the case of the high-income countries. These nations enjoy practically identical living standards today and a great deal of this is due to rapid convergence during the past four or five decades. However, this was not just a result of technological diffusion and related gains from trade. Not only were there important local deviations and adaptations in the diffusion process itself but also high growth was led and sustained by rising wages which enlarged home markets in these countries. The coincident growth of home demands, together with US hegemony and the Bretton Woods institutions, also ensured the rapid growth of international trade without threatening conflicts between external and internal balance.

The convergence of productivity and income levels in Europe and Japan to those prevalent in the US accelerated the growth of intra-industry trade and investments among these regions as firms took advantage of new market opportunities and exploited the economies of scale that came with inter-penetration of each other's markets. Indeed, world trade is dominated by trade among the high-income countries and the great bulk of it is of the intra-industry type i.e., presupposing similar economic structures and levels of living. Moreover, as these countries prospered, protectionist barriers to trade also came down in successive rounds. In short, income convergence produced external market integration both `automatically’ and by inducing policy change, not only the other way around.

For the LDCs, it is useful to begin with an empirical assessment of LOOP. The major finding of the International Comparisons Project is that countries' overall commodity price levels, for any given year and when expressed in a single currency, are positively related to their real income per capita (see Summers and Heston, 1991). Thus, the price level in the US tends to 
be 2.5 to 5 times the price level (converted at nominal exchange rates) in most poor countries. Underlying the price level differences are also price structure differences affecting both tradables and non-tradables that the ICP has documented. Among the major structural differences are a much higher relative price of services in richer countries ${ }^{17}$ and a much higher relative price of food in poorer countries (Summers and Heston, 1991). Hence, the failure of LOOP to hold as between rich and poor countries is massive indeed.

Turning next to time trends in price levels, Table 3 presents data on the distribution of world incomes for 1960-1989. The first two columns show the Gini coefficient of inequality for per capita GDP at international prices (purchasing power parities or PPPs) and at national prices. The rise in these inequality coefficients is consistent with our findings about growth divergence. This is indicated also in the next two columns which show the range of per capita incomes in the world measured as the ratio of the share of world income received by the top $20 \%$ of the world population to that of the bottom $20 \%$ of the population, once again in nominal and PPP terms. Column [5] shows the ratio of the two ratios (respectively at nominal and PPP terms) and represents the price level facing the top quintile of the population relative to that facing the bottom quintile. This ratio is, of course, greater than 1 in all years and, more remarkably, has risen sharply from 1970 until 1989. In other words, the price structures of poor countries have been deviating further over the past twenty years from those of the rich countries. Contrary to the trend toward apparent global integration, the Law of One Price seems to have grown progressively less valid. This is the `price dual' of the divergence in growth rates replicating the

17 As these authors point out, though this is the prime stylized fact of the ICP, it is also the most open to question on account of the difficulties of allowing for quality differences in the case of services. 
relationship between price levels and income levels over time.

Table 4 provides further evidence of price level variations over time and across country groups based on World Bank data. The Exchange Rate Deviation Index or ERD is measured as the ratio of GDP at international prices relative to GDP at national prices ${ }^{18}$. Since both are measured in terms of the US\$ as numeraire, the ratio is the (weighted average) international price level relative to the respective country's national price level $\left(\mathrm{P}^{\mathrm{IP}} / \mathrm{P}_{\mathrm{i}}^{\mathrm{NP}}\right)$. Following the ICP results, this ratio is greater than one for LDCs and negatively related to income levels. Table 4 shows that the (unweighted) ERD rose 18\% for the low-income countries between the two periods, fell $18 \%$ for the high-income countries and rose marginally (3\%) for the middle-income countries. Thus, price levels have risen faster than world price levels for the rich countries while the reverse has been the case for poor countries.

Table 5 shows the results of regressing the ERD on the (log of) per capita incomes in the pooled sample for 1960-95. We know from the ICP that the pure cross-section relation between ERD and income is negative. However, in a pooled sample, ERD variations reflect not merely the changing denominator of ERD (each country's own price level) which is related to income but also a changing numerator insofar as the weights of different countries in determining the international price level are changing. The latter source of variation arises if countries (or country groups) do not all enjoy identical growth rates which we know to be true in the present sample. This explains the mixed signs and statistical significance of coefficients in Table 5. The ERD is inversely related to incomes for each sub-period and for the whole period only in the case

18 These are both taken at current prices for each year and therefore free from the influence of inflation. 
of the high-income countries. For the whole sample, the inverse relation holds only in the second period; it is actually positive (though not statistically significant) in the first period and the whole period. This finding also applies for the middle income countries while for the low-income countries, the inverse relation holds for each period but not for the whole period.

Evidence over several decades thus fails to sustain the expectation of growing price convergence from growing globalization; the general conclusion must be that both incomes and price structures differed much to begin with and have continued to diverge. These findings call for a reassessment of the theoretical basis for favoring liberal, free trade policies i.e., the mechanisms that are routinely adduced to assert a connection between free trade and growth.

In conventional trade theory, countries gain from trading with each other ${ }^{19}$. But empirical estimates of the gains from trade liberalization rarely amount to more than one or two per cent of the liberalizing country's income. A graphic example is provided by the the GATT reforms involving virtually the whole world. Despite all the vaunted benefits from free trade, the latest round of GATT agreements is estimated to produce no more than $\$ 250$ billion in gains (about $1 \%$ of GDP in the year 2000) for the world economy of which the lion's share accrues to the OECD nations, especially the US, Japan and Germany. These small one-shot gains are dwarfed by the cumulative growth rate differences that liberal enthusiasts wish to attribute to trade regime differences. Over time, therefore, the defense of openness has shifted by invoking several other mechanisms.

One response has been to elaborate a new political economy of the state which claims that

19 The discussion here is confined to the case for openness to commodity and technology trade; capital mobility will be considered separately below. 
state interventionism (not necessarily confined to trade) which generally creates rents breeds competition among rational market participants for those rents but the competition in turn dissipates real resources equal in value to the rents themselves. Although the rents created by interventions are captured by competing agents, the competition itself entails costs that are equal to the rents (so there are no net gainers of the rent). The resource cost of such necessarily

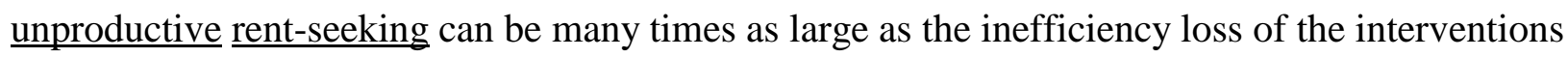
themselves. For trade interventions alone, typical "estimates" of rent-seeking waste are in the region of 10-20 per cent of national income ${ }^{20}$. However, neoclassical political economy misinterprets the nature of competition for state influence by mis-specifying the behavior of private agents and state functionaries alike. When respecified so as to be consistent with the neoclassical premise of rational action, rents created by interventions will be conserved ${ }^{21}$ rather than unproductively dissipated (see Rao, 1995).

A second line of defense links openness with superior productivity, product quality and product variety. There are several aspects to this link:

(1) Trade generates knowledge spillovers which, through reverse engineering for example, are beneficial to productivity and quality. However, such spillovers are indirect, incidental and uncertain. Profit-maximizing firms will seek out profitable knowledge wherever it might be; free trade is neither necessary nor sufficient (much less is it efficient) in conveying new knowledge to

${ }^{20}$ These estimates of waste are derived by simply equating them to the estimated value of rents created by state interventions.

${ }^{21}$ Private coalitions that succeed in creating rents for themselves through state interventions will also successfully capture the rents: rival coalitions will have no incentive to contest this capture so that no resource-using rent-seeking activity will be realized. Rents will then constitute purely redistributive transfers and therefore will be conserved. 
producers.

(2) Import competition has a disciplining effect on producers who are obliged to exploit cost and quality economies i.e., reduce `x-inefficiencies'. If competition has such an effect, this argument does not provide any reason why it must originate in international trade; presumably, domestic competition can serve the purpose just as well. More fundamentally, such an effect is inconsistent with the basic neoclassical premise that firms maximize profits. For if they do, then, they will minimize unit cost (or the cost/quality ratio) regardless of the degree of competition.

(3) Import liberalization increases consumer welfare by enhancing choice in the varieties they consume. While this is true particularly in poor economies with small home markets, this link is tenuously relevant, if at all, to explaining visible measures of economic performance such as growth and export competitiveness as opposed to the invisible consumer gains from variety ${ }^{22}$.

If the old trade theory is too feeble to support the weight of the neo-liberal position regarding free trade, the new trade theories may appear to vindicate that position on new foundations. How far is this the case from the viewpoint of the South? The new theories are based on decreasing cost due to scale economies, product differentiation among firms and associated market structures of oligopoly or monopolistic competition ${ }^{23}$. As domestic and international firms producing similar products compete in each other's markets, the resulting intra-industry trade may yield gains in the form of increased product diversity or promotion of competition, the latter arising from the curtailment of monopoly power which serves to increase

${ }^{22}$ The argument also supposes that domestic producers have no interest in making the productivity or quality improvements in the first place.

${ }^{23}$ Smith (1994) provides a lucid survey of the main lines of inquiry in this mold. 
output. It is this last type of gain that matters for present purposes: as markets are integrated, markets shares of monopolistically competitive firms, for example, are reduced, outputs rise and, given scale economies, costs fall.

However, intra-industry trade does not necessarily produce net gains for the trading countries $^{24}$. But the more central issue is the relevance of intra-industry trade for the South. Factor proportions remain crucial for the new theories as much as for the traditional theory. Inter-industry trade based on comparative or complementary advantage takes place between dissimilar economies whilst intra-industry trade based on absolute or competitive advantage characterizes similar (high-income) economies. The bulk of North-South trade is of the former type $^{25}$. Even much manufactured export from the South is of standard products based on established technologies. Whereas equalized incomes drive the pattern of trade within the North, the pattern of specialization and trade supports if not inducing non-equalization of factor prices between North and South. In fact, the absolute difference between average wages in the North

${ }^{24}$ In the product diversity case, if goods with high fixed costs displace others with low fixed costs, the net gains from diversity may turn out negative. More to the point, intra-industry trade may also incur additional transport, advertising and selling costs while promoting competition. Once again, trade may produce net losses. These ambiguities arise from the fact that intra-industry trade adds its own distortion while reducing an initial distortion. In the European Community, estimates of gains from trade integration (including competition promotion and scale economies) amount to about 5 per cent (Hine, 1994: p. 258). But even there, the home market retains its importance "with the largest part of virtually every market being taken by domestic firms" (Smith, 1994: p. 57). Similar preferences are believed to obtain even more strongly in Japan and in South Korea. In effect, these endogenous barriers allow monopolistic firms to retain substantial discretion in pricing.

${ }^{25}$ According to Hamilton and Winters (1992) 70 per cent of the variation in trade flows among a sample of 76 countries was explained by variables measuring national 'proximity' such as incomes rather than variables measuring national differences, a reflection of the large share of North-North trade. But exports from the South are primarily to the dissimilar North. 
and the South has been growing ever larger for close to two centuries ${ }^{26}$. Hence, North-South inequality (in the sense of absolute differences) must be understood in terms of uneven development i.e., dynamic factors making for persistently or even progressively different (physical and human capital) endowments.

Taken together, these observations deriving from established trade theories imply that the mechanisms for trade gains that are actually applicable to LDCs yield gains from trade liberalization that are empirically rather slight. They are far from the magnitudes required to sustain the orthodox view that illiberal trade explains the failure of living standards to converge. To be sure, LOOP need not hold even in orthodox theory. There are two standard arguments both of which serve to explain why neither factor prices nor commodity prices may be equalized. The first is the differential productivity argument (see Balassa, 1965) according to which poor countries have a roughly similar level of productivity in services (or non-tradables such as services) but a lower level in tradables. (Even) if free trade equalizes tradables' prices, factor prices (basically wages) will be lower in the poor countries and so will the relative price of services.

The second argument is that free trade in technologies and products does not logically guarantee factor price equalization. If factor endowment ratios are sufficiently far apart (as is evidently the case between the North and the South), then, specialization without factor price equalization will hold ${ }^{27}$. With their high relative endowment of labor, LDCs will specialize in

${ }^{26}$ What matters for the factor price equalization theorem are wage levels and not their long-term relative convergence (if any) so the 'convergence debate' is beside the point here.

${ }^{27}$ Factor intensity reversals within the available technologies must also be assumed away. 
labor-intensive goods and have low wages. The low wages, in turn, help explain the low relative price of services which are taken to be both non-tradable and relatively labor-intensive (Bhagwati, 1983). Thus, factor mobility has an independent significance in assuring full assimilation unless the economies are already similar to start with.

However, these 'explanations' of non-convergence amount to merely reformulating the question at hand. Why are there productivity differentials at all (let alone in the hypothesized directions)? Similarly, why is capital not sufficiently mobile across countries? If we leave out persistent, economy-wide increasing returns so that convergence is not ruled out right at the outset, then, we are left with two broad hypotheses. First, we may suppose (a) that there does indeed exist a large unexploited potential for arbitrage gains through international economic relations but (b) that there are barriers to its exploitation due to inherent market failures. Typically, these barriers include monopoly power in commodity and, especially, technology markets as well as the imperfect mobility of capital. We may call this hypothesis global market fragmentation. Second, we may suppose that the potential for arbitrage gains is in fact small because productivity differentials across economies cannot be bridged by trade, technology or capital flows. Rather, productivity differentials narrow only as a process of local learning, skill development and knowledge spillovers advances. We may call this hypothesis localization (of development). Fragmentation implies that tradable factors important to growth are not much

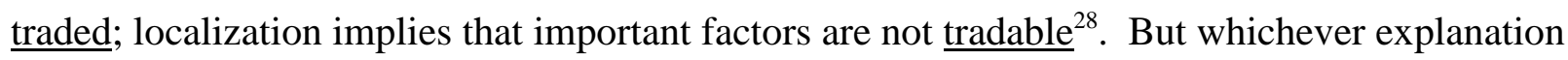
one may choose (actually, the two are not unrelated and there are sound reasons to combine the

${ }^{28}$ It is indeed true that labor is non-traded only due to artificial restrictions. But in a neoclassical two-factor world, factor price equalization requires mobility of one factor at best, not of both. 
two), this cannot be any consolation for the neo-liberal viewpoint. Capital market fragmentation is taken up in the next section leaving localization to be considered in the following sections (except as the two may be closely related).

\section{FRAGMENTED FINANCE}

There is an obviously profound imbalance in the capital available per worker or consumer between the rich and poor countries. Coupled with the large differences in technologies employed, the potential economic returns to making finance available to the South are large. Though the objective need and opportunity for saving and outside finance for physical, human and infrastructural capital formation is evident, it does not follow that the market, whether internal or international, is willing and able to supply these.

The neo-liberal presumption is that barriers to the Law of One Price in finance are purely policy-induced. Policy reforms that secure openness to global financial markets and internal financial liberalization will both serve to remove financial bottlenecks to development in the South. A relatively closed financial system has or entails controls on interest rates, exchange rates and the capital account, and the regulation of credit allocation - in short, financial 'repression' that produces inefficiencies in both portfolio holdings and in investment allocation. Internal liberalization stimulates domestic saving and improves its allocation via financial markets. Integration permits global market forces to determine interest rates, bond and equity prices and the foreign exchange rate. Removing capital controls brings about full risk diversification on the saving side and the optimal level of investment independent of domestic 
saving $^{29}$. The objective financing needs noted above will find full expression in such a globalized setting, the real interest rate will rise and capital will flow in to meet those needs. Though this is only a level effect, economic growth will accelerate over an extended period of time.

Even if the fragmentation of global finance were to be dismissed as temporary and that equalization will rule in good time, this characterization fails in terms of the 'flow' variables that will presumably bring about international convergence. According to World Bank data, total capital flows amounted to $\$ 273$ billion in 1995 . But this was a mere $1 \%$ of world GDP in that year and only $4.3 \%$ of gross investment world-wide. And even this flow is heavily concentrated among a handful of nations as Table 6 shows. Just 18 countries each receiving at least $1 \%$ of the world total account for $91.4 \%$ of the total flow. Low-income countries received a mere $\$ 20$ per capita, middle-income countries got $\$ 44$ per capita and the high-income nations received $\$ 185$ per person.

That these flows can, in some countries, finance a sizable portion of gross domestic investment is evident from Table 7. Leaving the high-income countries aside, we find that a half dozen countries (Hungary, Nigeria, Namibia, Poland, Nicaragua and Mauritius) financed at least a fifth of their domestic investment from foreign sources. But these exceptions confirm the general rule that finance tends to be strongly national rather than international. Even among the rich nations of the west, saving and investment rates are strongly correlated. As a result, the costs of capital range widely. The real interest rates faced by LDCs on their foreign debt, which

29 The collection of studies in Reisen and Fischer (1993) lays out several of these arguments in detail. 
is the money rate adjusted by the rate of change in their dollar export prices, are more than three times the rates experienced by developed countries (Avramovic, 1993). Profit rates remain dispersed even if short-term rates of interest show a degree of convergence due to the enormous increase in short-term financial movements.

Recent work by Epstein (1995) finds little evidence that there has been an increased tendency for investment to move in response to international differences in profit rates. While FDI is not unresponsive to relative rates of return, there is no perceptible increase in response over time ${ }^{30}$. The lack of integration in the supply of long-term finance has several sources. One pertains to international economic (particularly financial and exchange-rate) instability that has grown since the mid-1970s. However, increased "instability" as indexed by the increased variability of exchange rates and inflation rates failed to account for the failure of profit rates to equalize or for the persistence of profit rate variability. Rather, it is the lack of third-party enforcement of international financial and investment transactions coupled with the decline in US hegemony that, according to Epstein's empirical analysis, must bear the burden of explanation.

Other considerations, based on North-South distinctions, are also relevant. While the barrier of geographical distance in financial markets has dissipated over time, the global flow of finance remains constrained by real-side factors favoring localization. Whereas technological distance has risen between core and periphery, formal and informal alliances among firms in the North proliferate with investment tending to become more inward-looking. Just as intra-industry

${ }^{30}$ Of the 21 countries in Epstein's sample, 11 were LDCs or NICs - Brazil, Chile, Colombia, India, Ireland, Mexico, Panama, Philippines, South Africa, Spain and Venezuela. 
goods trade preponderates among the rich countries, similarly gross flows of investment within the North are substantially greater than net flows ${ }^{31}$. The importance of corporate retentions in financing investment means that a large volume of saving and investment get recorded in the same country. Hence, enforcement and sovereign risk concerns pose a much stronger NorthSouth barrier than within the North ${ }^{32}$.

Capital flows (whether direct investments or portfolio flows) seem to follow development rather than lead it. This is suggested by a regression analysis in which the dependent variable is capital flows (relative to GDP) averaged over 1991-95 and the independent variables are per capita income (in constant US\$) in 1990 and the growth rate of income during 1979-1992 (as computed for our convergence analysis of section 2). For the whole sample of countries, we get the following equation:

$$
\begin{aligned}
& \left(\mathrm{CF}_{\mathrm{i}} / \mathrm{GDP}_{\mathrm{i}}\right)_{1991-95}=1.9 \mathrm{E}-02-7.87 \mathrm{E}-07\left(\mathrm{y}_{\mathrm{NP}-87}\right)_{\mathrm{i}, 1990}+7.21 \mathrm{E}-04\left(\mathrm{~g}_{79-92}\right)_{\mathrm{i}} \\
& \begin{array}{lll}
(0.003) & (0.000) & (0.001)
\end{array} \\
& (*) \quad(* *)
\end{aligned}
$$

(standard errors are in parentheses and adjusted $\mathrm{R}^{2}$ equals 0.035$)^{33}$. The coefficient of initial income is negative and significant at the 5\% level while the coefficient of past growth though positive is not significant. This appears to indicate that global capital flows are "well-behaved"

${ }^{31}$ The rise in the share of services, which tend to be non-tradable, to unprecedented proportions in the rich countries may also be relevant. To the extent that services are dominated by smaller firms whose capital and management tend to be much more proprietorial and nationally rooted than those of large corporations, finance becomes more nationally oriented.

${ }^{32}$ Although trade-related risks have hardly vanished within the North, the present levels of internationalization of gross corporate holdings would appear to provide a strong joint interest if not full insurance against enforcement failures.

${ }^{33}$ Throughout, asterisks denote significance levels as follows: *(1\%), **(5\%), ***(10\%). 
i.e., the less developed the country, the greater its net receipts of capital flows relative to GDP. A closer examination of the influence of initial income shows, however, that the sample bifurcates at a per capita GDP of about $\$ 2000$. The regression equation for the sub-sample of coutries with $\mathrm{y} \leq \$ 2000$ is:

$$
\begin{aligned}
& \left(\mathrm{CF}_{\mathrm{i}} / \mathrm{GDP}_{\mathrm{i}}\right)_{1991-95}=7.68 \mathrm{E}-03+1.38 \mathrm{E}-05\left(\mathrm{y}_{\mathrm{NP}-87}\right)_{\mathrm{i}, 1990}+7.77 \mathrm{E}-04\left(\mathrm{~g}_{79-92}\right)_{\mathrm{i}} \\
& \text { (0.005) (0.000) (0.001) } \\
& (* *)
\end{aligned}
$$

(with an adjusted $\mathrm{R}^{2}$ of 0.069 ) whilst the corresponding equation for countries with $\mathrm{y}>\$ 2000$ is:

$$
\begin{aligned}
& \left(\mathrm{CF}_{\mathrm{i}} / \mathrm{GDP}_{\mathrm{i}}\right)_{1991-95}=2.47 \mathrm{E}-02-9.33 \mathrm{E}-07\left(\mathrm{y}_{\mathrm{NP}-87}\right)_{\mathrm{i}, 1990}-8.03 \mathrm{E}-04\left(\mathrm{~g}_{79-92}\right)_{\mathrm{i}} \\
& (0.003) \quad(0.000) \quad(0.002) \\
& (*) \quad(* * *)
\end{aligned}
$$

(with adjusted $\mathrm{R}^{2}$ equal to 0.147 ).

For countries that have achieved a modicum of economic development, equation (3) shows that capital flows do move inversely with initial income. However, for the low-income sub-sample, equation (2) shows that the level of development actually has a "perverse" effect on capital flows. If we suppose that in a properly functioning market, capital would flow from capitalabundant to capital-scarce regions, then, the above equations indicate that the global capital market malfunctions at least for countries below a threshold level of development.

This brief review of available evidence is sufficient to underscore the point that financial markets are profoundly fragmented and localized. This reflects risk and enforcement concerns of investors as also the importance of local development processes. The location of production depends on the comparative costs of immobile factors which are not confined simply to raw labor and land, the obvious ones. The (local) development process is also intensive in human capital accumulation and investments in infrastructure. It is not merely that the services provided by 
such investments are attached to the immobile factors and strongly complementary to movable capital investments in tradable sectors. It is also the case that there are financial market failures owing to significant externalities and information asymmetries which place these investments largely outside the scope of both indigenous and especially international market finance.

Consider investments in human capital. It is well known that social returns to human capital would hardly be fully internalized even if credit markets were perfect. Knowledge- and training-based externalities are a core feature of the localization of development. In developing countries, increments of expenditure even on nutrition, leave alone education and training, are major productivity-raising factors. While they are certainly privately ‘profitable', poverty and the lack of collateral, aggravated by moral hazard and adverse selection, render market financing either impossible or costly. Far from financing such productivity-raising expenditures, the utter inadequacy of credit markets forces a reliance upon self-provisioning and self-insurance which detract from productivity ${ }^{34}$.

Similarly, the low levels and quality of infrastructure help explain the low overall productivity, including low rates of return to capital, in LDCs. Free trade obviously cannot enable a country to specialize away from its requirements of these non-traded goods! But the pertinent question here is whether global finance can help. Many elements of infrastructure are characterized by external benefits if not outright jointness in consumption, non-excludability except at prohibitively high cost, increasing returns due to substantial indivisibilities and long payoff periods. Some of these features, particularly non-excludability e.g., in national highways

34 The lack of credit and insurance markets is a critical factor, for example, behind 'accumulating' precautionary and old-age saving in the form of children. 
or the supply of rural power, are peculiarly strong in underdeveloped countries due to both technical and social conditions. User charges are often limited even below the efficiency price (which itself must be below full cost) in the interest of political or price stability. On the other hand, investment and operating costs that 'need' to be recovered are also typically inflated by the malfeasance of managers, whether private or public. Hence, by rational design or institutional default, infrastructural services must be extensively subsidized.

The above difficulties acquire weight from the fact that infrastructural and human capital investments account for a sizable share of total investments in the low-to-middle range of national per capita incomes. While these considerations on the requirements of and returns to vital pieces of the local development puzzle, in conjunction with financial market failures, do suggest why their financing if not operation spills over into the public domain, they do not by themselves pose insuperable barriers. The problem however is that few states in the South muster either the political will or the administrative capacity, by way of tax effort, that this spillover requires. While fiscal constraints do not arise wholly on account of the need to finance current and investment outlays for development, public investment is often the first victim of fiscal troubles. At any rate, modern states' development ambitions customarily run well ahead of their incomes or borrowing capacities. Squaring off the books has been accomplished through forced finance: by monetizing the deficit and forcing saving via inflation or by requiring domestic banks, through reserve and portfolio requirements, to accommodate government finance. Forced saving and financial repression both have their limits (and both have been used to the hilt presumably because it is even more difficult to extract taxes from the wealth-holding 
public $)^{35}$.

These difficulties of public finance get compounded when we take account of the fiscal structures of developing countries. On account of the tax effort/compliance problems alluded to above, there tends to be a high reliance on commodity taxation and especially trade taxation. This dependence is strongly supported by a regression of trades taxes (relative to GDP) on per capita income for the 1990s:

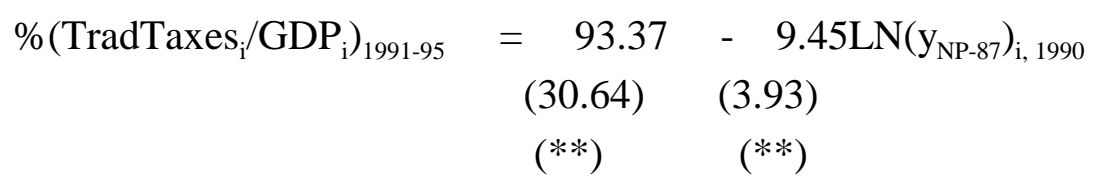

(with an adjusted $\mathrm{R}^{2}$ of 0.30 ). Countries with low per capita incomes tend to have a high ratio of trade taxes relative to GDP. Hence, any attempt at "trade reform" by eliminating trade taxes threatens to worsen the endemic fiscal problems of LDC states: the result must be a further constriction of development finance whose adverse effects may be reasonably expected to outweigh the meager gains (if any) that trade reforms per se must produce.

Consider now the implications of integrating such a fragmented domestic financial system with global financial markets. Even assuming that capital flows in rather than out, financial openness in the South not only provides no guarantee of macroeconomic stability but, on the contrary, adds its own not inconsiderable risks. In response to an inflow, either the reserve accumulation may be maintained together with the exchange rate or an exchange appreciation

35 Even within the normal market domain of business finance, however, financial markets in developing countries are far removed from the textbook model. See Rao (1995b) and (1996) on the role of informal/formal financial dualism in economic growth. 
prevents the reserve accumulation. The latter option is likely to de-industrialize by enlarging the non-tradable sector and promote speculative investments, both hurting long-term competitiveness. Presumably, nations in the South will eschew such a course. Portfolio flows are also liable to conflict with foreign direct investment. The maintenance of high interest rates to attract the former whilst the exchange rate appreciates is apt to discourage FDI. Thus, while trade reform may encourage FDI, financial liberalization works in the opposite direction.

On the other hand, the accretion of reserves with a pegged exchange rate will be inflationary and finance a bout of consumption or, worse, capital flight, rather than productive investment. If it supports a pick up in investment, "the country is `borrowing short to invest long' which exposes it to potential crises" (Patnaik and Chandrasekhar, 1995: p. 3009). But even assuming that this can be got around by choosing short-gestation, export-oriented investment, what ensures that there is an agent and a motive to undertake that investment? State withdrawal under structural adjustment that is the very basis of the liberalization makes it the unlikely agent; inducing private investors with the carrot of reduced interest rates "can scarcely be used for fear of frightening international rentiers" (ibid.). Short of fiscal mobilization, stepping up public investment must also confront the same constraint as it is the market, under liberal dispensation, that will determine what a sustainable level of the fiscal deficit will be. Sterilized interventions (or managed floating) are also severely circumscribed by (a) the limited capacity of the central bank to issue bonds (given the shallowness of the domestic securities markets); (b) negative fiscal consequences from the consequent pegging of domestic interest rates; and (c) adverse consequences for the private sector from the credit squeeze (Reisen, 1993: p. 47-8).

It is in this light that the success of relatively liberalized financial regimes in Malaysia 
and Indonesia since the early 1970s (and Singapore since the 1960s) must be understood. Fundamentally, it is the exceptional fiscal strength of their states that helped them avoid macroeconomic instability and the loss of competitiveness in the face of large capital inflows. The Singapore Government's chief policy instruments in achieving the world's highest rates of saving were essentially coercive: the use of state monopolies to extract rents in such nontradables as land and housing, public utilities, the port, telecommunications, etc. and high rates of compulsory savings via the Central Provident Fund, a social security scheme (Huff, 1995). Sterilization is accomplished through transfers of excess savings controlled by the state into and out of the banking system. In Malaysia and Indonesia, a major share of export revenues came out of oil and other extractive industries which were largely state-owned as was also the banking system in Indonesia (Sen, 1995). Hence, the budget surplus tracks reserve movements and so does central bank credit to the government. This frees up the interest rate from demand management and can be directed instead to steady the exchange rate.

To sum up, national financial markets within the South present a picture of deep structural fragmentation. Finance flows but unevenly among the modern industrial sector where much of the learning process must concentrate, the informal and agricultural sectors which are the prime sources of employment and livelihoods and the public sector which must play the leading role in creating infrastructural and human capital. The asymmetries that underlie the lack of financial integration within nations are rooted in both political and market failures. In turn, indigenous financial markets, even when not closed by policy, are but poorly connected with global markets: the lack of integration of production and real investment is mirrored in large enforcement or country risk premia. Besides, openness itself is constrained by the weak 
domestic fiscal and financial structure. In short, the hierarchical fragmentation of global financial markets is both constitutive of and caused by the localization and unevenness of development.

In this structural context, attempts at opening up place local development processes at considerable risk of rupture or slackening. Following the theorem of the second best, financial integration in the presence of structural asymmetries may cause further divergence rather than convergence. Adverse effects are not confined to the probable distortion of development priorities that will ensue. In the longer term, even net flows may tend in the 'wrong' (from the perspective of the South) direction. That is, reverse flows may not be the result only of debt crises and associated capital flight. In recent years, profit rates in the advanced countries have trended upward. If the uptrend is real and not the result of reversible factors such as real wage reductions and reductions in input prices (energy and raw materials) but due to irreversible productivity advances based on technical change, then, there is a prospect of "further flight of capital from developing to developed countries and continuing and perhaps accelerated migration of both skilled and unskilled labor" (Avramovic, 1993: p. 4-5).

By comparison with capital mobility, integration via labor mobility would provide a far more reliable and powerful mechanism for reducing international inequalities. But as small as North-South capital movements are, the South-North movement of labor remains smaller still. Indeed, the pattern of labor movements being encouraged may aggravate, not narrow, international inequalities. Thus, the selectivity of immigration policy favoring the skilled is largely inimical to the interests of the South while the liberalization of labor immigration is hardly on the North's agenda. 


\section{ACCUMULATION AND STRUCTURAL CHANGE}

Traditional development economics concerned itself mainly with the analysis of the structural determinants of low incomes and productivity and the means by which they might be overcome. Structures and incomes, in this approach, evolve together. Inspired in many ways by classical economics, most of its practitioners consciously rejected neoclassical theory ${ }^{36}$. While structuralist theory predicted stylized patterns of economic growth and had much to say about development policy, it was remarkably silent about speeds of growth or convergence across countries. Thus, a growing LDC might replicate an advanced country's path and pattern in considerable detail - ranging from family fertility behavior to the commodity pattern of international trade - but conceivably diverge forever. In this regard, it stands in direct contrast with the currently fashionable revival of neoclassical ('old') growth theory which focusses on the fact of international divergence only to attribute it to permanent dissimilarities of underlying structures (and safeguarding the theory thereby).

This theoretical contrast reflects fundamental differences not merely of vision but also of method. On the first count, development economists believed that relative economic backwardness presents both opportunities and constraints, both at home and on the external front, and that the latter must be overcome by coordinated public action. Methodologically, they emphasized the possibilities of increasing returns, indivisibilities and externalities (as do the socalled 'new' growth theories) but did not care to place these inside mechanistic models

${ }^{36}$ Apart from Kuznets' (1966) pioneering empirical work, see also Rosenstein-Rodan (1943), Nurkse (1953), Lewis (1954), Hirschman (1959), Streeten (1959) and Chenery and Syrquin (1975). 
predicting unbounded divergence. Rather, they viewed development in terms of long processes of transition between steady states separated by institutional change. Such institutional change could not be readily predicted and formed, instead, the starting point of the analysis (see Arida and Taylor, 1988). It is in this sense that their approach must be seen as a series of open rather than closed models.

While structural patterns provide important guidance about the transitions, they were seen neither as necessarily optimal nor as inevitable. Predictability did not imply controllability or realizability (in any particular case) either via the market or by the state. The debate over balanced and imbalanced growth underscored the value at once of both coordinated balance and creative imbalance (across sectors). The policy precepts of development theory could be summarized as accumulate (capital), diversify (into modern industry), mobilize (surplus labor and other hidden reserves) and coordinate (private actions, rather than leave it to the market). That these lessons have borne fruit and not ceased to be important is broadly attested to by experience (see Sen, 1983).

While capital accumulation remains the centerpiece of this approach, its potential is structurally nuanced. Thus, low incomes and low (essentially agricultural) productivity are held to be a cause of low saving rates. But rather than this implying a perpetual low-level trap, structural change (particularly shifts in the modes of production) aided by state interventions e.g., an induced agricultural revolution, and state coordination of investment can simultaneously lift saving rates and incomes even if only gradually. Pooled evidence on saving and investment rates in our sample of 123 nations for the $1960-95$ period confirms the strength of the structureaccumulation relationship. 
Regressing the saving-to-GDP ratio and the investment-to-GDP ratio on per capita income yielded the following results:

$$
\%\left(\mathrm{~S}_{\mathrm{it}} / \mathrm{Y}_{\mathrm{it}}\right)_{\mathrm{NP}}=-13.414+4.311 \mathrm{LN}\left(\mathrm{y}_{\mathrm{NP}-87}\right)_{\mathrm{it}}
$$

(with an adjusted $\mathrm{R}^{2}=0.238$ ) and

$$
\%\left(\mathrm{I}_{\mathrm{it}} / \mathrm{Y}_{\mathrm{it}}\right)_{\mathrm{NP}}=\underset{(0.691)}{9.797}+\underset{(0.095)}{1.680 \mathrm{LN}\left(\mathrm{y}_{\mathrm{NP}-87}\right)_{\mathrm{it}}}
$$

(with an adjusted $\mathrm{R}^{2}=0.076$ ). In both equations, the variable on the right hand side is per capita income at constant national prices and converted at prevalent exchange rates while the left hand side variables are current-price ratios.

But the ICP reveals large differences in the relative price of investment across countries. It falls systematically as per capita income advances. That is, investment goods are relatively expensive in low-income countries. Heston and Summers (1991) maintain that the "major explanation for this price pattern undoubtedly lies in the area of public policy" but explicitly refrain from elaborating any further. Presumably, this is a reference to trade protection policies for industry particularly in the area of capital goods. While the reason for varying investment prices does not directly concern us here, it is worth pointing out that it is by no means obvious that public policy is the major explanation. The ICP data show not only that the relative price of "producer durables" (or capital goods) falls steeply as we go from the poorest group to the richest group of nations but that the relative price of construction too enjoys a virtually identical decline. Yet, the construction component accounts for a larger share of domestic investment in all groups of countries and construction is an example of non-tradables par excellence. Unlike the price of 
tradable capital goods, there is no manifest channel through which public policy can effect a systematic drop in the price of construction. On the other hand, the latter may well be a reflection instead of a faster rise in construction productivity ${ }^{37}$. Moreover, considering that most LDCs are still quite heavily dependent on imports to meet their capital goods requirements, we cannot rule out the possibility that the higher prices of these goods they face is the result of transport costs and monopoly market power of sellers ${ }^{38}$.

At any rate, given the observed price patterns, identical nominal (or national-price) investment rates represent variable real investment rates across the income ladder ${ }^{39}$. We therefore recomputed regression (6) with the investment ratio as well as per capita income at international prices to get ${ }^{40}$ :

$$
\%\left(\mathrm{I}_{\mathrm{it}} / \mathrm{Y}_{\mathrm{it}}\right)_{\mathrm{IP}}=\underset{(0.879)}{-31.612}+\underset{(0.113)}{6.258 \mathrm{LN}\left(\mathrm{y}_{\mathrm{IP}-85}\right)_{\mathrm{it}}}
$$

(adjusted $\mathrm{R}^{2}=0.438$ ). The upshot of this revision is that the elasticity of investment rates with respect to real income is amended upwards substantially. This is also brought out clearly in terms of country GDP-weighted average rates of accumulation in Table 8. For the period 1979-

${ }^{37}$ It should be noted that this is also an anomaly within the ICP results the most notable of which is that there is a steep and continuous $\underline{\text { rise }}$ in the price of non-tradable services. For the same reason, we must reject Nuxoll's view that the inverse relation between investment prices and incomes is due to the facts that (a) services experience lower productivity growth than manufacturing and (b) investment "includes mostly manufactured goods" (1994, p. 1425).

38 Monopoly power that could lead to price discrimination.

39 Whereas real investment rates represent the effect of accumulation, saving rates, on the other hand, represent the effort expended at accumulation. The latter are best measured at the prices actually facing savers in each country i.e., at National Prices.

${ }^{40}$ We used the chain index constant price measure of per capita income but the investment ratio is measured at current (though international) prices. 
95, we find that real investment rates are in the ratio of roughly 1:2:3 as among low-income, middle-income and high-income countries whereas in nominal terms the differences are smaller (in fact, the difference between the high-income and middle-income groups is negative $)^{41}$.

Next consider the variation in GDP structure with respect to income. Table 9 shows the industry share of GDP by income group and period. Across countries, the share rose with income in both periods. Over time, however, industry's share declined in all three groups of countries (though more sharply in the advanced countries). For the advanced countries, this "deindustrializaton" is widely regarded to be a reflection of the well-known rise in the share of services. For the low- and middle-income groups, on the other hand, the de-industrialization would appear to be a consequence of several factors working together. First, there was an adverse movement in the terms of trade which in some cases may have hurt industry more than other sectors. Second, many countries whether voluntarily or under pressure of debt, carried out tariff and quota reductions that reduced relative industrial prices and probably also real industrial output relative to GDP. Finally, the decline in economic growth rates between the two periods (which resulted in absolute reductions in per capita incomes in many countries) may also be held partly responsible.

Returning to the cross-country pattern, it is desirable, once again, to take account of the systematic variation of relative prices with income to get a more accurate picture of the importance of industrialization in economic development. The ICP clearly shows that the price of services rises monotonically with the level of per capita incomes. However, the ICP only gives relative prices for expenditure components of GDP, not relative prices by sectors of

${ }^{41}$ Directionally similar results also obtain for the first period. 
production. Hence, we are not able to arrive at sectoral real shares of GDP that can be compared cross-nationally. Assuming however that relative price differences in respect of services constitute the overwhelming sources of differences between nominal and real shares across countries, we may compare the share of industry in GDP exclusive of services ${ }^{42}$. In effect, we choose to compare the share of industry in what may be called "gross material product". This is shown against the head "NS-GDP" in Table 9 for each period and group. This comparison shows that the industry share (for 1979-1995) reckoned in terms of NS-GDP rises far more sharply across country groups than when reckoned in terms of GDP - from $27 \%$ to $65 \%$ to $79 \%$ as against $19 \%$ to $28 \%$ to $32 \%{ }^{43}$.

More generally, this comparison is also sustained in the appropriate regressions of the industry share on per capita income as shown below:

$$
\begin{aligned}
(\text { IndShareGDP } & -0.032 \\
& (0.008)
\end{aligned} \quad \begin{aligned}
& 0.044 \mathrm{LN}\left(\mathrm{y}_{\mathrm{NP}-87}\right)_{\mathrm{it}} \\
& (0.001)
\end{aligned}
$$

(adjusted $\mathrm{R}^{2}=0.289$ ) and

$$
\left.(\text { IndShareNSGDP })_{\mathrm{it}}\right)_{\mathrm{NP}}=-0.862+0.182 \mathrm{LN}\left(\mathrm{y}_{\mathrm{NP}-87}\right)_{\mathrm{it}}
$$

(adjusted $\mathrm{R}^{2}=0.587$ )

The elasticity of the GDP share of industry is only 0.16 (from equation 8 ) whereas the elasticity

${ }^{42}$ We are less certain of the claim frequently made (see, for example, World Bank, 1997) that the positive relation between the nominal share of services in GDP and per capita income is entirely due to rising services prices and not a real phenomenon at all.

43 Another revision concerns the change over time in the industrial share. For the middle-income countries, a slight nominal decline (from $29 \%$ to $28 \%$ ) is actually a smart real rise (from 54\% to 65\%) whereas for low-income countries the real share declines as does the nominal. 
of its non-services-GDP share is 0.35 in equation (9). Though our "correction" for relative price differences is only an informed guess, it suggests that the positive relationship between industrialization and economic development is considerably stronger when taken in "real" than in nominal terms.

Orthodox economics including trade theory has no explanation for this central stylized fact of the patterns of growth among nations. In the "old" doctrine of comparative advantage, there is no reason why agricultural nations should be poor and industrial nations rich (and vice versa). In the "new" theories of trade, it can be supposed, with some justification, that it is chiefly the industrial sectors that enjoy economies of scale and scope for product diversification. But this only implies that intra-sector trade will preponderate in industry as opposed to agriculture and that intra-sector trade will take place between similar economies as opposed to dissimilar ones (which will be dominated by comparative advantage). It does not imply that rich economies must be industrial and poor ones agricultural.

It would seem that increasing returns must be made part of the picture but not in the "unstructured" way that the "new" growth theories posit. We would do better to return to the "old' theories of increasing returns. Adam Smith and other classical economists recognized the role of growing specialization as a key factor in productivity growth. Young (1928) extended Smith's idea by pointing out that as aggregate production expands, new processes, products, intermediates and sub-divisions of work come into being which reduce costs and prices. The division of labor is limited by the extent of the market (Smith, 1776) which is limited in turn by the division of labor (Young, 1928). Such dynamic external economies cannot be privately appropriated and may even be purely external to all existing industries (since the set of industries 
is itself variable $)^{44}$.

But the dynamic economies of specialization may be disproportionately large in certain types of production activity i.e., some of these economies may be specific to these types. Modern industry (rather than agriculture) appears to be the prime example of activities with dynamic external economies as is perhaps evident from the unambiguous connection between the share of industry and per capita income across nations noted above. Since it is the principal specialization of the North, sector-specific increasing returns seems to be a factor in explaining why growth rates differ. Growth based on industry-specific external economies amplifies uneven development based on structural asymmetries (i.e., large differences in capital-labor ratios and patterns of specialization). This is, therefore, a major reason for fostering industrialization in developing nations ${ }^{45}$. It recalls the early development economists" recognition of the "infant industry" argument, not just in the orthodox trade-theoretic sense but in the sense of an infant

44 If the division of labor is limited by the extent of the market, then, globalization is obviously productivity-enhancing and integration through free trade will benefit North and South. Apart from the fact that this conclusion is not the basis of the neo-liberal case for trade, two arguments hold against it. To the extent that capital is not perfectly mobile, the South's participation in the global division of labor will be stunted and so will be its gains. Second, if increasing returns are sector-specific, these activities will be located in those nations that have a head-start in them. Although specialization is therefore national, other nations can also benefit from it by buying the relevant products from the specialized nation (assuming markets are competitive). But this requires that the pattern of trade equalizes factor prices (Krugman, 1987). If factor prices are not equalized (because of structural asymmetries or capital immobility), then, the gains will not accrue to the nations whose factor prices are not equalized with those of the specialized nation(s).

45 This leaves open the question whether such increasing returns are unbounded. In fact, developed countries have experienced both rising wages at home and a rising share of services in GDP. If services are subject to decreasing rather than increasing returns and if wage growth slows down capital accumulation, there is at least the potential for a slowing down if not reversal of increasing returns. 
"industrial sector" whose range of activities is evolving rather than fixed and whose evolution generates increasing returns (including or even mainly externalities).

But the desideratum of diversification into industry has not merely a positive basis (as above) but also a negative one, not just a supply-side argument (as with increasing returns) but also a demand-side mechanism. Diversification is a strategy of development not only because of the gains that accrue thereby but also because of the losses that are avoided. Confronted with two centuries of increasing inequalities among nations (which included significant periods of wide-open national economic borders), both early development economists and theorists of dependency and underdevelopment argued that the inherited international division of labor is part of the problem, not part of the solution (Prebisch, 1959, Singer, 1950 and Frank, 1966; also Palma, 1978). Prebisch, Lewis (1954 and 1978) and Emmanuel (1972) formulated various versions of the idea that international exchange between rich and poor nations is unequal. Unequal exchange arises from structural asymmetries in product markets or in labor markets given complete specialization. The inability of the South to catch up by accumulating capital (even if capital is mobile) is because of the pattern of specialization in which it finds itself. The South specializes in low demand-elasticity primary goods while the North produces high demand-elasticity consumption goods and capital goods. Prebisch (1950) argued along this line that balanced North-South growth and trade will produce dynamic terms of trade losses for the South owing to the lower income elasticity of demand for its export compared to its import. Alternatively, the South must face slower growth with fixed terms of trade. While productivity improvement in either region reduces its barter terms of trade, it is likely to raise the double 
factoral terms of trade of the North but reduce the double factoral terms of trade of the South ${ }^{46}$. In other words, productivity improvements in the South are liable to be lost through trade while similar improvements in the North are liable to be retained there. Deliberate industrialization in violation of the South's comparative advantage emerges as the way out of this fix ${ }^{47}$.

Much ink has been spilt over the measurement and interpretation of statistical trends in the terms of trade of primary goods relative to secondary goods (or of LDCs relative to the highincome countries). We are persuaded that the evidence rests on the side of those who maintain that the trend has been broadly negative (see Sarkar and Singer, 1991). But this is not the point we wish to press here. Let us suppose instead that the evidence revealed no adverse trend against primary products or against LDC exports. This would not by itself vitiate the argument due to Prebisch and others. For one, the evidence on divergence supports the argument: $\underline{\text { had }}$ there been convergent (or at least non-divergent) growth, then, the terms of trade would have trended down. For another, many countries have actually undergone some diversification which should have served to preempt the decline: the Prebisch prediction is, in this sense, a self-defeating but true prophecy.

The classic developmental arguments for industrialization, from both supply and demand sides, amply help explain the observed structural relations of both quantity and price i.e., the structure of GDP in relation to income and the terms of trade between poor and rich countries. Clearly, the contrast between the structural versus the neo-liberal predictions and prescriptions

46 The double factoral terms refer to the ratio of per capita (strictly, per worker) incomes in the two regions.

47 On North-South models of unequal exchange and development, see Ocampo (1986), Evans (1988) and Dutt (1990). 
(in relation to the empirical facts of income divergence and international dis-integration) could not be greater. Further support for the structural approach obtains from cross-country comparisons of openness to trade and the composition of trade.

Table 10 presents average (both simple and weighted) levels of openness in the crosscountry sample for the two time periods. Since the ICP has worked out international prices for every component of expenditure, the PennTable directly gives openness - exports+imports as \% of GDP - at international prices (but see note 48 below). Two observations may be made. First, real openness (whether reckoned as simple or weighted means) rises significantly going from low-income to high-income countries in both periods. Second, all three groups of countries experienced a rise in their level of openness between the two periods (once again in simple and unweighted terms). This is unambiguous evidence of rising 'real' globalization world-wide. But the increases have not been uniform for all groups of countries. Considering simple country means, we find that the openness ratio has risen $27 \%$ for high-income countries, $18 \%$ for middleincome countries and only $13 \%$ for low-income countries. In terms of weighted means, however, the respective increases amount to $42 \%, 20 \%$ and $32 \%$ respectively. It follows that larger economies within each of the groups have become more open but this trend has been particularly dramatic for the low-income group. The last finding, paradoxically, reflects the high growth of large (and therefore relatively more closed) economies, particularly China and India, during a period when many small (and therefore relatively more open) economies languished.

We regressed the PennTable measure of openness on per capita incomes at constant international prices and, following the usual practice (see Syrquin, 1986, for example), on size measured by population to get 
$\%$ OPENNESS $_{\text {it }}=\underset{(6.493)}{181.889}+\underset{(0.543)}{11.676 \mathrm{LN}\left(\mathrm{y}_{\mathrm{IP}-85}\right)_{\text {it }}}-\underset{(0.327)}{13.301 \mathrm{LN}(\mathrm{POP})_{\text {it }}}$

$(*)$

(adjusted $\mathrm{R}^{2}=0.344$ ). Thus, controlling for 'economic size', we find that openness rises sharply with the level of development ${ }^{48}$.

What accounts for this `structural’ or cross-country relation between openness and per capita incomes (and size for that matter)? Consider size first. Population size rises statistically with land area and therefore (statistically) with a diversity of natural resource endowments. The latter makes possible greater production diversification to meet domestic demand in large than in small countries. As for the link between openness and income, start with the observation that the real share of industry is strongly related to income. Industry affords greater possibilities for product diversification and specialization than the primary sector. Hence, (intra-sector) trade in industrial products is advanced relatively easily whereas trade in agriculture is limited by natural resource-based comparative advantage. The positive relationship between openness and income follows as a consequence. A second consideration is that economic development that comes from industrialization makes possible and is made possible by external economies secured in the production of infrastructure (social overheads such as transport, communications, energy

48 The ready availability of data on openness at international prices in the PennTable certainly makes for more appropriate cross-country comparisons. Indeed, regressing openness measured at national prices on per capita income (and controlling for size) gave a positive but statistically insignificant relationship. But the PennTable measure of openness does not eliminate the problem of comparability. Services are far less tradable than non-services (services accounted for $18 \%$ of world trade but around $50 \%$ of world GDP) and it is not altogether implausible to suggest that the real service share does rise with incomes. 
production and other factors $)^{49}$. This growth or improvement in infrastructure that industrialization, to some extent, makes possible then renders international trade more feasible or efficient.

In the light of the structural viewpoint and its empirical basis analyzed above, it should come as no surprise that export composition (in terms of the share of manufactures in merchandise exports) is also generally systematically related to income levels. Table 11 shows that the (unweighted mean) export share of manufactures rises with income in both periods and that that share has risen between the two periods for all income groups. The increase over time is also more marked for both low-income and middle-income countries than for the rich countries, a straightforward result of Engel's Law (at the world level) $)^{50}$.

\section{INTERNAL INTEGRATION}

Although the historical record of economic development provides strong support for the structural viewpoint as opposed to the neo-liberal one, the policy prescriptions apparently drawn from that viewpoint - including, perhaps especially, the emphasis on the role of the state in the tasks of raising saving rates, diversifying economic structure and coordinating investment - have

49 This is also related to our earlier point concerning the declining relative price of construction that is observed in the ICP data. See footnote 37.

50 Cross-country regressions of export composition yielded a positive and significant coefficient for the years 1965 and 1979 but the coefficient was not significant for 1991. This may simply reflect the enormous weight of manufactures in total exports today (saturation effects) and shows that manufactures require to be disaggregated suitably to capture the spirit of the Prebisch et al. argument. 
come under a heavy barrage of criticism. Absolute divergence, paradoxically, appears to be the touchstone of this (primarily neo-liberal) critique. Despite all the historical support it has garnered, it must be reiterated that structural development theory does not offer any firm hypothesis regarding convergence or divergence. But because growth rates remain an important part of the 'bottom line' of development, this critique, though misplaced, has tended to stick.

The canonical form of this critique is summarized in the statement that "the state cannot pick winners". Should a country move into capital-intensive industries today just because it will have future comparative advantage in them? Again, if an industry promises high returns, why don't private investors develop it? These rhetorical questions are meant to dispel the view that there is any advantage in state coordination of the development process.

Whatever may be the economic possibilities for industrial policy in the advanced countries at the frontiers of technology, LDCs are clearly not at the frontiers. Structural change that will come with success is broadly predictable even if not in every detail. Post-war experience shows clearly that administrative guidance succeeded in helping Japan (and South Korea afterward) catch up with the advanced west. From the viewpoint of the South, this by itself is of great significance ${ }^{51}$.

A specific form of the counter-argument here has to do with the linkage between accumulation and industrialization. Suppose that a capital-intensive industry would generate a relatively high saving rate because of its high profit share. Then, the decision to invest in it today will alter the future resource endowment of the country in a `structurally favorable' way i.e., raise future productivity and incomes. Thus, the very act of investing in the industry will also raise its

\footnotetext{
51 See Amsden (1989), for example, on Korea.
} 
profitability the magnitude of such an effect depending on the size of the industry. When such an effect covers a broad spectrum of industries, investment coordination becomes potentially very valuable for development ${ }^{52}$. Apart from differential saving propensities, other linkages arise on account of differential learning propensities, differential rates of skill-generation and knowledge spillovers, differential fiscal effects (that will accordingly affect the rate of development of public infrastructure that can raise private productivity), etc. What structural patterns help establish is the existence of such broad connections which can be taken advantage of through strategic coordination. Precisely because the linkages involve broader aggregates such as sectors rather than just individual firms or industries, the issue at hand is poorly described by the phrase "picking winners". Indeed, industrial policy in East Asia should be seen not as a tactic for picking winners but as a strategy for achieving overall industrial advance whatever may be the method of selecting and favoring particular industries.

Coordination failures can mean not only foregoing potential gains but also incurring avoidable losses (as in the case of diversification away from the primary sector) ${ }^{53}$. Whether manufacturing protection is helpful or not depends on what the counterfactual is; it is not established merely from the ex post observation of success or failure. For example, a protected industry may not become competitive either because the North's competitiveness rises or because there is too much competition within the South. It does not follow that the country would have been better off specializing according to static comparative advantage if that would have made

${ }^{52}$ This argument holds so long as we do not suppose that the market optimizes the rate of saving for all time.

${ }^{53}$ That this may entail international coordination is not any reason to ignore the argument about diversification. 
matters even worse. That is, even if protection does not render manufacturing competitive, it may be a loss-minimizing strategy.

This brings us to the predicament (not just advantage) of backwardness or `late industrialization'. Industrialization and accumulation without effectively absorbing (if not improving upon) imported technologies cannot produce successful growth (or convergence). But just as we have seen that finance capital offers resistance to becoming a pure commodity across national frontiers, so too does technology. Although technology is indeed bought and sold, its value-in-use is liable to differ significantly from its price (or potential) depending on the buyer's own capabilities to absorb it. As lead technologies have advanced, hurdles to leapfrogging the technical learning process have increased (see Fransmann, 1985). This unfortunately results in overcrowding of the lower rungs of the development escalator. The international transmission of consumption patterns that are import- and capital-intensive adds another hurdle. As a result, many countries in the periphery are unable to develop competitive advantage fast enough to achieve industrial take-off but nevertheless have to bear the costs of technological backwash effects and the marginalization of a large part of their populations.

Arguably, the industrialization imperative of the post-War period has contributed to, not created, the pronounced discontinuity between formal and informal sectors and markets. In an earlier era, the influx of industrial imports from the industrializing west and the growth of export specialization and enclaves - producing primary agricultural products and minerals - was promoted through direct interventions in the traditional economies of the colonies. The economic basis of traditional producers, both agrarian and artisanal, was disrupted not only by the new competition from industrial products but also by discriminatory policies of taxation, 
resource control and infrastructural investment - policies that were designed to create labor supplies for plantations, cash crop production and mining. Both economic dualism and underemployment are a legacy of this era as was the particular division of international labor.

Late industrialization built on this inheritance through imports of technical and organizational forms typical of industrialized countries. But the rapidly advancing technology lag has been difficult to bridge in most developing countries. In many cases, this transplantation has been effected suddenly and without a prior transformation of the traditional agrarian and nonagricultural sectors. The segmentation of capital and labor markets has been supported by and, in turn, reinforced this discontinuity. Nor was the knowledge acquisition process informed by significant adaptation to local conditions. Production relations in the formal sector - featuring strict hierarchy, minimal worker participation and the attempt to separate knowledge from execution - faithfully conformed to the Taylorist model. There has also been a strong proclivity to vertically integrated firms, reliance on full-time, permanent workers and in-house supervisors. But in other respects, the acquisition and learning process was quite dissimilar. The abrupt transition from agricultural to factory production without any intervening merchant-craftsman stage obviated the de-skilling process of early Taylorism. Yet, the labor force had to be trained and adapted to industrial conditions and, successful adaptation and learning ultimately hinged on both enterprise strategies and the environment in which they had to function.

The continuing, in many cases growing, gap in productivity and wages across the developed/developing divide has allowed or required a greater reliance on firm strategies oriented to cheap labor rather than continuous development and improvement of technology as the basis of competitive advantage. Competitive advantage thus obtained mainly from static 
labor cost advantages is not only fragile but also quickly lost. Late industrialization has therefore been vulnerable to external strangulation manifesting in bouts of foreign exchange, fiscal and debt crises. State policy has often been obliged to hide and underwrite the resultant losses through protection and subsidies ${ }^{54}$.

The East Asian success stories in many ways conform to the classic stance of development economics - success underwritten by high rates of saving, industrialization and state coordination and planning. Yet, they also demonstrate key areas where traditional development theory suffered from want of emphasis if not from outright neglect. The East Asian NICs had enjoyed a special concatenation of external and internal political circumstances in the decade or two following the second World War. These compelled and enabled their states to launch successful land reforms (in Taiwan and Korea), invest in mass education and health, and in other ways establish a growth regime that spread the fruits of rising incomes. The unusual mix of authoritarianism and an inclusive social base for growth, by design and circumstance, allowed the state to discipline capital and labor without posing excessive problems of disciplining the state itself. Following Japan's lead, the East Asian NICs were able to give a good account of this social capital in achieving export competitiveness in manufacturing. The crisis of Fordism in the advanced economies even as liberal trading arrangements continued to grow afforded the NICs a golden opportunity to make inroads into OECD markets, an opportunity they had been well prepared to take advantage of. In many ways, China appears to have followed a similar course though lagging its neighbors by a decade or two.

54 A significant part of the growth of the public sector in many developing countries is also the result of late industrialization in the above sense. 
In this light (and other sources of hindsight after due passage of 'world time'), it is probably fair to say that traditional development policies suffered from a number of lacunae: (1) the tendency to overemphasize physical capital accumulation and to treat technology as a commodity caused human capital to be neglected; (2) linking inequality and industry with higher rates of saving may also, in some cases, have caused inattention to the tasks of an agricultural revolution (including the problem of ridding rural inequalities which often stood in the way of such a revolution) so necessary to successful industrial growth; (3) inequality also adversely affected the pace of human capital development, worsened fiscal barriers to developing infrastructure, depressed the inducement to invest and prevented the pursuit of appropriate macroeconomic policies; (4) finally, while private myopia in investment and trade was to be forestalled through state coordination, this coordination itself was seen as a purely technical affair (and thus its implementability and benefits were apt to be overestimated).

To sum up, whilst neo-liberals see productivity and income growth arising automatically from external integration, development theory tended to see growth as flowing equally smoothly from coordinated structural change. While the former takes the internal integration of the economy to be an accomplished fact, the latter did not anticipate the political and economic hurdles that made internal integration far from automatic or smooth. In a globalizing world, the problem for developing countries is not so much that external integration threatens internal disintegration. Rather it is that external integration may abort a healthy process of internal integration that is practically a defining element in successful development.

National competitiveness relative to the global economy proceeds from a base of internal integration. The intra-national division of labor, as Adam Smith observed, is limited by the 
extent of the market: specialization is a public good producing external benefits that are jointly consumed. In addition, public infrastructure investment (in transport and communications, education, research, extending the land frontier, major irrigation, etc.) raises productivity both directly and by extending the home market while, the development of state institutions (enactment and enforcement of laws, tax collecting machinery, maintaining order, etc.) serves to expand the state's revenues. As the market expands, the costs of running the state and delivering infrastructure services fall and state revenues increase at the same time. These make possible an increased supply of infrastructure which further extends the home market. Hence, the expansion of the home market and modern state formation feed on each other in cumulative fashion and add to national competitiveness. Similarly, while an initially significant productivity lag seems almost inevitable in agriculture relative to industry and in informal activities relative to the formal, a successful process of internal integration must dissove these lags progressively over time. Failure of such internal convergence to take place is not an effect of unsuccessful development; it frequently is an important cause of it.

At the same time, a half century of experience shows that it does not follow, merely from demonstrating the developmental value of national autonomy, that the state will exercise its autonomy successfully. Modern state formation has been no less problematic than the process of economic modernization or development as the history of western Europe demonstrates ${ }^{55}$. Constraints originate both from conflicts in civil society and from failures within the state. In

55 Modern state formation in Europe was spread over a few centuries. It is no accident, as the above argument suggests, that this history coincided with the age of mercantilist protectionism. The late modernization and development of Italy despite an early start with citystate merchant capitalism reflects the failure of state formation and internal integration. 
many parts of the South, the four or five decades following the retreat of colonialism have seen intense state-building activity and attempted modernization. The complementarity between these processes noted above does not imply that they will be successfully prosecuted. The failures and reversals (as also the successes) in this effort cannot be understood except in political terms i.e., in terms of the conflicts generated by the social embeddedness of both state and economy.

The value of national autonomy in the South arises from the structural and market asymmetries identified in the preceding sections. In the poor countries of the world, the project of national integration and locally-oriented development must, as in the past, continue to take precedence over the project of globalization. But this is an economic project only to the extent that it is a solved political problem. The quality of public interventions and participation is therefore fundamental to its realization.

\section{POVERTY AND INEQUALITY WITHIN NATIONS}

We have seen that international inequalities of income have risen over time including the past two decades when the forces of globalization have clearly been unprecedentedly strong in both rich and poor nations. The overall rate of expansion of the world economy has also been slower on average during the past two decades than during the Golden Age. The slower rate and unequal spread of global growth are both cause for concern from the point of view of reducing absolute poverty and raising the minimal levels of living of people around the world. In addition, globalization introduces new sources of market vulnerability and instability that may be particularly harmful to those nations and groups that are already poor and vulnerable to begin 
with. To top it all, economies that are more open to trade and especially capital flows find it more difficult to follow autonomous macroeconomic policies. Many developing country governments have become fiscally fragile and lack the institutional and policy instruments that richer countries have to protect people against economic instability.

Income poverty remains persistantly high: calculations on the basis of a dollar-a-day poverty line (at 1985 international prices) show that that nearly a third of the people in the developing world are poor (see Table 12). Some dimensions of human poverty, such as malnutrition and poor reproductive health, afflict much larger percentages of people. In the long run, economic growth can no doubt be an important factor in reducing poverty. But the benefits of growth do not automatically trickle down to those who need them the most. Much depends on the character of growth itself and on the nature of redistributive and public expenditure policies in place. In previous sections, we have tried to argue that a uniform model of external integration for poor and rich countries cannot be optimal for growth itself. An additional reason for international differences in policy regimes derives from distributional goals.

We report below the result of a cross-country regression of the incidence of poverty below one international dollar a day. The independent variables include the log of per capita income at purchasing power parities, a measure of openness and government consumption expenditure relative to GDP.

$$
\%(\mathrm{BELOW} \$)_{\mathrm{it}}=\begin{array}{cccc}
152.47 & -17.03 \mathrm{LN}\left(\mathrm{y}_{\mathrm{IP}-85}\right)_{\mathrm{it}} & -0.025(\mathrm{OPEN})_{\mathrm{it}} & + \\
(36.64) & (04.36) & (0.097) & (0.469)
\end{array}
$$

(adjusted $\mathrm{R}^{2}=0.34$ ).

The regression shows a negative and statistically significant coefficient for the income variable: 
poverty is lower at higher levels of per capita income. However, the level of openness has no statistically significant direct influence on poverty. This should be seen in conjunction with the evidence in previous sections which suggest that the indirect influence of increased external integration on poverty (operating via its effect on economic growth and income levels) may be negative. The equation also shows that relative government expenditure has no significant effect on poverty incidence. It is worth noting that only $34 \%$ of poverty variation is explained by the above equation ${ }^{56}$. Thus, economic growth seems to be effective to the extent of explaining only about a third of poverty variations across nations. These last two observations suggest that success in poverty eradication depends on much more than economic growth. These are only preliminary results. Clearly, more work needs to be done in terms of disaggregating the nature of income growth and analyzing government programs (of transfers, subsidies and expenditures that help the poor) before a more complete explanatory picture of poverty can be put together.

Income inequality within nations is undoubtedly a major factor underlying human development or deprivation. A more equal distribution of wealth and income is the basis of a more equal distribution of the good things including education, health and the ability to participate in social life. Some international differences in inequality may derive from relatively deep-seated historical differences. Nevertheless, at least since the time of Simon Kuznets, economists have hypothesized that income inequality varies with per capita income. Specifically, Kuznets hypothesized that inequality at first rises with per capita income, reaches a

${ }^{56}$ The explained proportion rises to $38 \%$ in another specification with the per capita income variable alone. We should also remember that due to systematic differences in relative prices, poverty may be systematically underestimated in lower income countries. This will tend to understate the influence of income growth on poverty. 
peak and thereafter declines as income continues to grow. We fitted a cross-country Kuznets relation with the ratio of the income share of the richest $20 \%$ relative to that of the poorest $40 \%$ serving as the measure of inequality. For income, we employed the PennTable per capita income at international constant prices. The regression result is as follows:

$$
\begin{array}{rlll}
(\mathrm{INEQUALITY})_{\mathrm{it}}= & -37.584 & +10.924 \mathrm{LN}\left(\mathrm{y}_{\mathrm{IP}-85}\right)_{\mathrm{it}}- & 0.712\left[\mathrm{LN}\left(\mathrm{y}_{\mathrm{IP}-85}\right)_{\mathrm{it}}\right]^{2} \\
& (8.546) & (2.154) & (0.134) \\
& (*) & (*) & (*)
\end{array}
$$

(adjusted $\mathrm{R}^{2}=0.124$ ).

The regression strongly supports the Kuznets U-curve hypothesis with the peak inequality at a per capita income of $\$ 2,146$. The Kuznets process implies that economic growth at low levels of income tend to be unequalizing. It suggests also why high levels of poverty may persist stubbornly unless proactive povery alleviation programs and transfers are deliberately instituted. The influence of globalization on intra-national inequality operates through a number of channels the most important of which have to do with the sectoral structure of output, the structure of employment (by sector, skill intensities and wage rates), fiscal policies (the level and forms of taxation) and the overall level of employment. This is an area of high priority for future research. Apart from poverty and inequality, one other consideration that impinges directly on people's well-being and that may be intimately related to globalization is economic uncertainty. On the one hand, greater openness reduces income or consumption risks by allowing portfolio diversification and providing additional channels for the absorption of domestic shocks. On the other, it raises such risks particularly because of increased specialization in production and employment. Rodrik (1997) has shown convincingly that the empirical relation between income and external risks is significantly positive. Since his finding holds in the aggregate, the risks to 
particular classes of people must obviously be higher still. Since governments in LDCs have neither the fiscal means nor the institutional mechanisms through which the affected groups can be socially insured (and since most people in poor countries lack the means for private insurance), this must count as a major "invisible" element of the costs imposed by globalization invisible because it is apt to be masked by standard measures such as GNP which attract most attention. Rodrik makes a convincing case that the problem in the advanced countries is to ensure that global integration does not produce national disintegration. But for LDCs, the problem may be how to ensure that a fragile process of national integration in the making is not shattered.

Several of the general points made previously linking globalization and well-being either directly or indirectly through growth may be illustrated with the important example of agriculture and food security. Trade policy towards agriculture in developing countries - where, typically, domestic prices are held below the corresponding border prices - has been a focus of intense scrutiny from the neo-liberal standpoint. One aspect of it concerns food security directly. In the neo-liberal view, food imports or exports do not have to conflict with the objective of food security. On the contrary, the gains from specialization that obtain from trade make it easier for countries to pursue the goal of food security. The alternative view holds that exposure to narrow and unstable international markets is a major source of food price instability and associated food insecurity. Both vulnerable producers and consumers, lacking other means for achieving food security, would be better off in domestic markets that are, in some significant measure, sheltered from such instability. The other prong of the controversy has to do with the means for promoting equitable growth. Again, the neo-liberal claim is that international trade provides opportunities 
for developing countries to specialize and secure gains from trade. Hence, policies to secure domestic self-sufficiency are misguided and detract from long-run growth. As against this view, others insist that free trade provides the wrong signals from the viewpoint of economic diversification and equitable growth. These proximate goals of long-run development can only be pursued with domestic and trade policy instruments that, to a considerable extent, conflict with the policy of free trade.

This is not the place to evaluate this controversy in any detail. But our general point is easily made: even within the orthodox calculus, getting domestic food and agricultural prices in line with international prices will produce but a small gain in `national' welfare whereas the resulting redistributions of income will be of a large order of magnitude. There is no assurance whatsoever that these redistributions will enhance food security and reduce poverty; on the contrary, there is reason to believe that the rise in food prices will reduce per capita consumption of food and, that redistributions will expose vulnerable segments of the population to an increased level of food insecurity. In other words, the efficieny or growth gains promised by such "reforms" is small whilst the human costs produced by adverse redistributions will be large.

The simple reality in many poor countries is that if surpluses for export exist at all this is not because domestic needs have been met but because these are not backed by purchasing power. To the contrary, any expansion of exports driven by a price rise must further reduce that purchasing power; and the rise in export volumes may well dissipate part of the gains in the form of terms of trade losses. On the production side, if past experience is any guide, a large portion of the gains from increased prices is likely to be concentrated among well off farmers producing for export. Small farmers and less favored regions who do not produce crops or varieties for the 
export market are likely to experience the adverse effects of the rise in food prices without the benefit of seeing their own output prices go up.

The most appropriate policy for most developing countries is likely to lie between the extremes of free trade and self-sufficiency. This conclusion is based on several arguments that flow from the recognition that agricultural prices perform not merely the conventional allocative function but also critical redistributive and fiscal functions. First, while nations may attach different values to the political benefit of being self-sufficient, few are likely to reject trade altogether. However, for the same reason, nations must be free to choose the degree of selfsufficiency; unfortunately, the present tendency in world trading arrangements appears designed to curb such autonomy. Second, maintaining lower-than-world prices on average at home can be a powerful policy for promoting food consumption and food security especially for the poor. Similar orders of direct income support and transfer will prove administratively and/or fiscally infeasible. Third, increasing domestic food and agricultural output inevitably entails substantial public investment (in research, extension, irrigation, roads, education and other infrastructure) and/or input subsidies to propagate new technology adoption. Once again, the direct and full recovery of these costs from farmers will, in general, be neither efficient nor always feasible. Thus, low output prices and effective input subsidies can combine to promote both agricultural output growth and food security ${ }^{1}$. Finally, the maintenance of such an implicit tax/subsidy policy on average still allows for imports and exports of particular food and other agricultural commodities thus leaving open a basis for gains from international specialization. These arguments must be seen not merely as providing a foundation for prescribing policies; in various mixes, they also provide the best available basis for explaining the actual patterns of trade-based 
food and agricultural policies that we observe across developing countries (Rao, 1989) ${ }^{57}$.

\section{CONCLUSION}

In relation to economically advanced countries, globalization has elicited three dominant perspectives which also incorporate somewhat different definitions of globalizaton: (1) increasing transactions across national borders whose effects are relatively small and dominated by rapid perturbations of technology; (2) increased though imperfect mobility of capital which nonetheless threatens economic stability and national ways of life even as it erodes the economic basis of national autonomy; (3) policy convergence across nations which signals a new era of global integration to be brought about chiefly by commodity trade rather than capital movements. Clearly, these views differ over the role of globalization in influencing income distribution or producing income uncertainties and overturning established national standards. But they all affirm that unimpeded globalization promotes growth. From the viewpoint of the developing countries, on the other hand, unimpeded globalization has always appeared to be a double-edged even for economic growth: an opportunity and a threat. In the course of addressing their persistent problems of poverty and inequality, this two-sidedness is important for at least 2 reasons. First, growth is demonstrably important for reducing poverty and raising people's individual and collective capabilities. Second, insofar as levels of poverty and human development depend on the character of growth, we must know in what direction and how far

57 This is not to argue, of course, that observed policies are socially optimal; only, that the underlying constraints are sufficiently widespread among developing countries. 
this is influenced by globalization.

The empirical analyses of this paper, based on data for a wide cross-section of countries and for the periods 1960-78 and 1979-1995, sought to establish certain basic structural features of the global economy and of the place of developing countries in that structure. The salient findings may be summarized as follows. (1) Openness or trade relative to real GDP at international prices rose for all groups of countries and for the world as a whole but the rise was more pronounced for the high-income group. In general, openness remained strongly related to the level of development and this relation also diverged over time. (2) The rate of growth of per capita GDP is positively related to the initial level of per capita GDP for the whole period as well as the two sub-periods studied. Thus, incomes have on average diverged across the world - the rich becoming relatively richer compared to the poor countries. However, there is also evidence of "convergence clubs" in that groupings of nations by income level is internally convergent (the only exception being the low-income group during the second period). (3) International differences in price levels and price structures have been diverging despite the persistent trends towards increasing globalization. Reasons for these differences and divergences have to do with persistent polarities in capital-labor endowments across countries that are not much dented by rising trade and the sharply lower productivities especially in tradable goods. They call into question the liberal expectation that policies conforming to the Washington Consensus will produce real convergence through the price mechanism. (4) Although some differences still remain, the share of manufacturing in total exports has tended to converge across income groupings of countries. This is symptomatic of late industrialization whereby the operation of Engel's Law at the global level has tended to crowd many developing countries into the 
standardized, low-tech end of the tradables spectrum. (5) Despite the very pronounced increase in the gross short-run movements of financial capital, net real flows of capital remain rather slim relative to most nations' investment levels. Net capital flows are also heavily concentrated and, among low-income countries, tend to follow rather than lead development. (6) Although nominal investment rates seem broadly comparable across the income ladder, real investment rates (measured at common international prices) are in fact positively related to income levels and have diverged. (7) Real indices of industrialization continue to be positively related to national income levels. In recent decades, the real industry share has fallen somewhat in the lowincome countries and diverged internationally. (8) National differences in per capita income seem to explain only about a third of the international variations in poverty (with a poverty line based on one dollar a day in 1985 purchasing power parity prices) whilst cross-country variations in income inequality follow the Kuznets inverted-U shape in relation to per capita income.

The paper also considered several explanatory hypotheses for divergent growth trends. The first of these posits unequal "fundamentals" - the argument is simply that the long-run income levels toward which countries are growing are inherently or permanently different. Fundamental differences in respect of investment in education or returns from education, in preferences to consume today rather than save, in preferences for children and the like make absolute convergence impossible. But this argument "explains" the low growth rates of poor nations in terms of the very features that describe their poverty whereas it is well known that these features shift systematically as incomes rise. A second hypothesis, essentially the Washington Consensus, holds that it is policy impediments and policy impediments alone that stand in the way of international integration and full convergence of incomes. There are three 
principal difficulties with this view. First, despite rising global trade, we find incomes diverging rather than converging. Second, the argument generally explains the policy impediments to be the result of wrong political leadership. But this tells us nothing about what governs political choices. Finally, the benefits of integration have not flowed symmetrically at all income levels: convergence has been strongest for high-income countries. Even for the advanced countries, we must ask how convergence came about. Experience both before and after WW II seems to show that it is not integration alone that led the way to similar incomes; narrowing income differences too seem to have caused greater external integration. To put it differently, the relationship between exports and development is hardly a one-way street. Development creates new capabilities for export. Indeed, much of the trade in the world today is trade that presupposes similar incomes and economic structures rather than the other way around. Formally, the failure of international integration can be "explained" in terms of persistent productivity differentials and the imperfect immobility of capital. But these merely reformulate the question at hand. Before returning to this reformulated question, we must first consider the new growth theories. According to the "new" growth theories, the world seems to reveal not diminishing returns to capital but increasing returns. Here capital is understood to be a composite of investment in physical capital and human capital (education, training, R\&D). Learning by doing, knowledge spillovers and various agglomeration economies are chiefly responsible. The result is that the lead nations have a head start in the race and simply widen the gap between themselves and the late starters. Increasing returns theories, in a sense, "explain too much" for our purposes. Their validity is called into question by the fact that some countries have converged and a few continue to do so. 
Our own hypothesis builds around the ideas of market fragmentation and internal integration. Two broad hypotheses seem to be consistent with experience: (1) Fragmentation: global markets in goods/technologies/finance are fragmented rather than integrated so the gains from trade are not as large as they would otherwise be; (2) Localization: productivity differentials are not bridged by trade; rather, they narrow only as a process of learning, skill development and knowledge spillovers advances.

Nothing illustrates fragmentation better than the global financial markets. Several aspects of this fragmentation may be noted. First, empirically even the flows of finance across countries belie liberal or conventional expectations: they are small, concentrated and correlated positively with initial incomes. Finance tends to be strongly national rather than international, not because the world has necessarily taken Keynes' policy prescription to heart. Rather it must be explained in terms of (1) risk and enforcement factors and (2) the importance of local development processes in which local saving rates and local investment rates may be strongly inter-dependent. Second, there is an intimate relation between private and public finance. Several considerations are relevant here. (a) there are pervasive and well-known market failures in the private financing of human capital. (b) Observed private returns to investment frequently understate the social returns because of various forms of external benefits. (c) The lack of supportive infrastructure also leads to low observed rates of return on capital. The upshot is that infrastructure in the broad sense - both soft and hard elements or human and physical components of it - must be heavily subsidized and frequently publicly financed. Given limited and lagging tax effort, investments for development are often financed by forced saving or financial repression. Third, these difficulties are compounded by the intimate connection between government revenues and 
foreign trade. Trade "reforms" are apt to tighten fiscal constraints to development. Fourth, even the normal market domain of business finance is deeply fragmented, for example, between large and small firms or formal and informal enterprises or urban and rural sectors. In short, financial markets are fragmented both globally and inside developing countries. Finance flows but very sluggishly across the various segments. And attempts at external integration frequently add to instability and fragility.

As for localization, our basic point is that important elements that contribute to development cannot be arbitraged by international trade. Rather, they are essentially nontradable or "local" factors of productivity growth. These elements include: (a) learning, training and knowledge spillovers related to structural change of GDP; (b) human capital externalities not related to structural change as such; (c) infrastructural externalities; (d) positive or negative fallout from economic coordination, governance and redistributive issues (these have to do with the state and redistributive politics).

Traditional development theory, in common with classical economics, had important insights into the process of local development. As Amartya Sen noted at the dawn of the debt crisis, these insights are well supported in the empirical record. Apart from a rising share of investment, a rising share of industry in material GDP, of trade in GDP and of manufacturing exports in the total are the key factors here. These correlates of growth are not explainable by orthodox trade theory. But they can be understood in terms of many of the factors taken to be central in the increasing returns view but applied specifically to the industrial sector rather than the whole economy. There is also a negative argument for promoting industry that derives from the expectation that specialization in areas with low elasticities produces adverse movements in 
the terms of trade and/or lower economic growth.

Despite this support for a structural rather than neoliberal understanding of development, we should note certain key lacunae in traditional development policies. First, an overemphasis on physical capital accumulation and the tendency to treat technology as a commodity caused human capital to be neglected. Second, linking industry with increasing returns may, in some cases, have caused inattention to the tasks of an agricultural revolution so necessary to successful industrial growth. Third, the singular emphasis on the beneficial effects of inequality for saving also adversely affected the pace and spread of human capital development, worsened fiscal barriers to developing infrastructure, depressed the inducement to invest and prevented the pursuit of appropriate macro policies. Finally, while private myopia in investment and trade was to be forestalled through state coordination, this coordination itself was seen as a purely technical affair (and thus its benefits were apt to be overestimated).

What this suggests is that internal or national integration, taken to be a political-economic process, is neither an accomplished fact in developing countries nor automatically brought about. Quite the contrary: it is a fragile affair, perhaps more so in the time of globalization. Failure of such internal integration to take place is not an effect of unsuccessful development; it frequently is an important cause of it. And it is here that the value of national autonomy needs to be recognized in the context of a global economy characterized by structural and market asymmetries. In the poor countries of the world, the project of national integration and locallyoriented development must, as in the past, continue to take precedence over the project of globalization. But this is an economic project only to the extent that it is a solved political problem. The quality of public interventions and participation is therefore fundamental to its 
realization.

-74- 


\section{REFERENCES}

Amsden, Alice, 1989, Asia's Next Giant: South Korea and Late Industrialization, New York: Oxford University Press.

Amsden, Alice, Jacek Kochanowicz and Lance Taylor. 1994. The Market Meets its Match: Restructuring the Economies of Eastern Europe. Cambridge: Harvard University Press.

Avramovic, Dragoslav (1992). Developing Countries in the International Economic System: Their Problem and Prospects in the Markets for Finance, Commodities, Manufactures and Services. New York: United Nations Development Program. Human Development Report Occasional Papers No. 3.

Balassa, B., 1964, "The Purchasing Power Parity Doctrine: A Reappraisal," Journal of Political Economy, 72:584-596.

Barber, Benjamin, 1997, "Global Markets: Spur to Competition or the End of Diversity?", unpublished, Paris: UNESCO.

Barro, Robert J. and Xavier Sala-I-Martin (1992). Convergence. Journal of Political Economy. 100: 223-51.

Baumol, William J. (1986). Productivity Growth, Convergence and Welfare. American Economic Review. 76: 1072-85.

Baumol, William J., Richard R. Nelson and Edward N. Wolff (eds.), 1994. Convergence of Productivity: Cross-National Studies and Historical Evidence. New York: Oxford University Press.

Bhagwati, J., 1984, "Why are Services Cheaper in the Poor Countries?," Economic Journal, 94:279-286.

Boyer, Robert (1995). Capital-Labour Relations in OECD Countries: From the Fordist Golden Age to Contrasted National Trajectories. In Juliet Schor and Jong-Il You (eds.). Capital, the State and Labour: A Global Perspective. Aldershot: Edward Elgar and United Nations University Press.

Chenery, H. and M. Syrquin, 1975, Patterns of Development, 1950-70, London: Oxford University Press.

Clark, Gregory, 1987, "Why Isn't the Whole World Developed?: Lessons from the Cotton Mills," Journal of Economic History, 47.

Cox, Robert W. (1994). Global Restructuring: Making Sense of the Changing International Political Economy. In R. Stubbs and G. R. D. Underhill (eds.). Political Economy and the Changing Global Order. New York: St. Martin's Press.

Dutt, Amitava, (1990). Growth, Distribution and Uneven Development. Cambridge: Cambridge University Press.

Emmanuel, Arghiri (1972). Unequal Exchange. New York: Monthly Review Press.

Epstein, Gerald (1995).. International Profit Rate Equalization and Investment: An Empirical Analysis of Integration, Instability and Enforcement. In Gerald Epstein and Herbert Gintis (Eds.). Macroeconomic Policy After the Conservative Era: Studies in Investment, Saving and Finance. Cambridge: Cambridge University Press

Evans, David, 1988, 'Alternative perspectives on trade and development', in H. Chenery and T.N. Srinivasan (eds.), Handbook of development economics, vol. 2, Amsterdam: North- 
Holland, pp.1241-1304.

Frank, Andre Gunder, 1966, "The Development of Underdevelopment” Monthly Review, 18.

Fransman, Martin, 1985, "Conceptualizing Technical Change in the Third World in the 1980s:

An Interpretive Survey," Journal of Development Studies, 21.

Gerschenkron, A., 1962, Economic backwardness in historical perspective, Cambridge, MA: Harvard University Press.

Greider, William (1993). The Global Marketplace: A Closet Dictator. In D. N. Balaam and M. Veseth (eds.). Readings in International Political Economy. Upper Saddle River: Prentice Hall.

Griffin, Keith and Azizur R. Khan (1992). Globalization and the Developing World: An Essay on the International Dimensions of Development in the Post-Cold War Era. New York: United Nations Development Program. Human Development Report Occasional Papers No. 2.

Hamilton, Carl and L. Alan Winters (1992). Opening up International Trade with Eastern Europe. Economic Policy. 14: 77-116.

Hine Robert C. (1994). International Economic Integration. In David Greenaway and L. Alan Winters (eds.). Surveys in International Trade. Oxford: Blackwell.

Hirschman, Albert, 1959

Huff, W. G. (1995). The Developmental State, Government, and Singapore's Economic Development since 1960. World Development. 23: 1421-38.

Krugman, Paul (1987). Increasing Returns and the Theory of International Trade. In Truman Bewley (ed.). Advances in Economic Theory. Cambridge: Cambridge University Press.

Kuznets, S., 1966, Modern Economic Growth, New Haven: Yale University Press.

Lewis, W. Arthur (1954). Economic Development with Unlimited Supplies of Labour. Manchester School. 400-449.

Lewis, W. Arthur (1978). The Evolution of the International Economic Order. Princeton: Princeton University Press.

Lipietz, Alain (1995). Capital-Labour Relations at the Dawn of the Twenty-First Century. In Juliet Schor and Jong-Il You (eds.). Capital, the State and Labour: A Global Perspective. Aldershot: Edward Elgar and United Nations University Press.

Lucas, Robert E., 1988, "On the Mechanics of Economic Development." Journal of Monetary Economics. 22:3-42.

Mankiw, N. Gregory, David Romer and David N. Weil, 1992. "A Contribution to the Empirics of Growth." Quarterly Journal of Economics. 107:407-437.

McKinnon, R., 1973, Money and Capital in Economic Development, Washington, DC: Brookings Institution.

Nurkse, R., 1953, Problems of Capital Formation in Underdeveloped Countries, Oxford: Blackwell.

Nuxoll, Daniel A., 1994, "Differences in Relative Prices and International Differences in Growth Rates," American Economic Reiview, 1423-36.

Ocampo, Jose Antonio (1986). New Developments in Trade Theory and LDCs. Journal of Development Economics. 22: 129-70.

Palma, G., 1978, `Dependency: A formal theory of underdevelopment or a methodology for the 
analysis of concrete situations of underdevelopment?', World Development, July-August.

Patnaik, Prabhat and C. P. Chandrasekhar (1995). Indian Economy under `Structural Adjustment'. Economic and Political Weekly. Vol. XXX. No. 47. 3001-3013.

Prebisch, Raul (1959). Commercial Policy in the Underdeveloped Countries. American Economic Review. 49: 251-73.

Pritchett, Lant, 1996. Forget Convergence: Divergence Past, Present, and Future. Finance and Development, 33:40-43.

Rao, J. Mohan (1995). The Market for the State: Rules, Discretion, Rent-Seeking and Corruption. Department of Economics Working Paper No. 1995-3. Amherst: University of Massachusetts.

Rao, J. Mohan (1995b). Financial Liberalization, Capital Rationing and the Informal Sector in Developing Countries. In Gerald Epstein and Herbert Gintis (Eds.). Macroeconomic Policy After the Conservative Era: Studies in Investment, Saving and Finance. Cambridge: Cambridge University Press.

Rao, J. Mohan, 1996, "Globalizaton: A View from the South," unpublished, Amherst: University of Massachusetts (January 1996).

Rao, J. Mohan, 1997, “Culture and Globalization," unpublished, Amherst: University of Massachusetts (May 1997).

Rao, J. Mohan, 1989, "Getting Agricultural Prices Right," Food Policy, Vol. 14, February 1989, pp. 28-42.

Reisen, Helmut (1993). Macroeconomic Policies Towards Capital Account Convertibility. In Helmut Reisen and Bernhard Fischer (editors). Financial Opening: Policy Issues and Experiences in Developing Countries. Paris: OECD.

Reisen, Helmut and Bernhard Fischer (editors). Financial Opening: Policy Issues and Experiences in Developing Countries. Paris: OECD.

Rodrik, Dani, 1997, “Has International Integration Gone Too Far?” unpublished, Cambridge: Harvard Univesity.

Romer, Paul M., 1986, "Increasing Returns and Long-Run Growth," Journal of Political Economy, 98:S71-102.

Rosenstein-Rodan, P., 1943, "Problems of Industrialization in Eastern and Southeastern Europe," Economic Journal, 53:202-211.

Sachs, Jeffrey and Andrew Warner (1995). Economic Reform and the Process of Global Integration. Brookings Papers in Economic Activity. 1-118.

Sarkar, P. and H. Singer, 1991, "Manufactured Exports of Developing Countries and their Terms of Trade since 1965," World Development, 19:333-340.

Schwartz, Hermann M. (1994). States versus Markets: History, Geography and the Development of the International Political Economy. New York: St. Martin's Press.

Sen, A.K., 1983, “Development: Which way now?” Economic Journal, 93:745-762.

Sen, Sunanda (1995). On Real-Financial Sector Nexus and Financial Opening. Paper presented at a conference on The State and Development in Asia. New Delhi: Jawaharlal Nehru University.

Singer, H., 1950, "The distribution of gains between investing and borrowing countries," American Economic Review, 40:377-382. 
Smith, Adam, 1985 [1776], An Inquiry into the Nature and Causes of the Wealth of Nations, New York: The Modern Library, 1985.

Smith, Alasdair (1994). Imperfect Competition and International Trade. In David Greenaway and L. Alan Winters (eds.). Surveys in International Trade. Oxford: Blackwell.

Srinivasan, T. N., 1985, "Neoclassical Political Economy, the State and Economic Development," Asian Development Review, 3:2, pp. 38-58.

Streeten, P., 1959, 'Unbalanced growth', Oxford Economic Papers, 11:167-190.

Summers, R. and A. Heston, 1991, "The Penn World Table (Mark 5): An Expanded Set of International Comparisons, 1950-1988," Quarterly Journal of Economics, 327-368.

Syrquin, M., 1988, "Patterns of Structural Change" in H. Chenery and T.N. Srinivasan (eds.), Handbook of Development Economics, vol. 1, Amsterdam: North-Holland, 203-273.

Taylor, L. and P. Arida, 1988, "Long-run Income Distribution and Growth," in H. Chenery and T.N. Srinivasan (eds.), Handbook of Development Economics, vol. 1, Amsterdam: NorthHolland, 161-194.

Tullock, G., 1993, Rent Seeking, Edward Elgar: The Locke Institute.

World Bank, 1997, World Indicators. Washington, DC: World Bank.

World Commission on Culture and Development (1995). Our Creative Diversity. Paris: UNESCO.

Young, Allyn (1928). Increasing Returns and Economic Progress. Economic Journal. 38: 527542. 
TABLE 1 Countries Ranked by Level and Growth Rate of Per Capita Income (Constant International Prices)

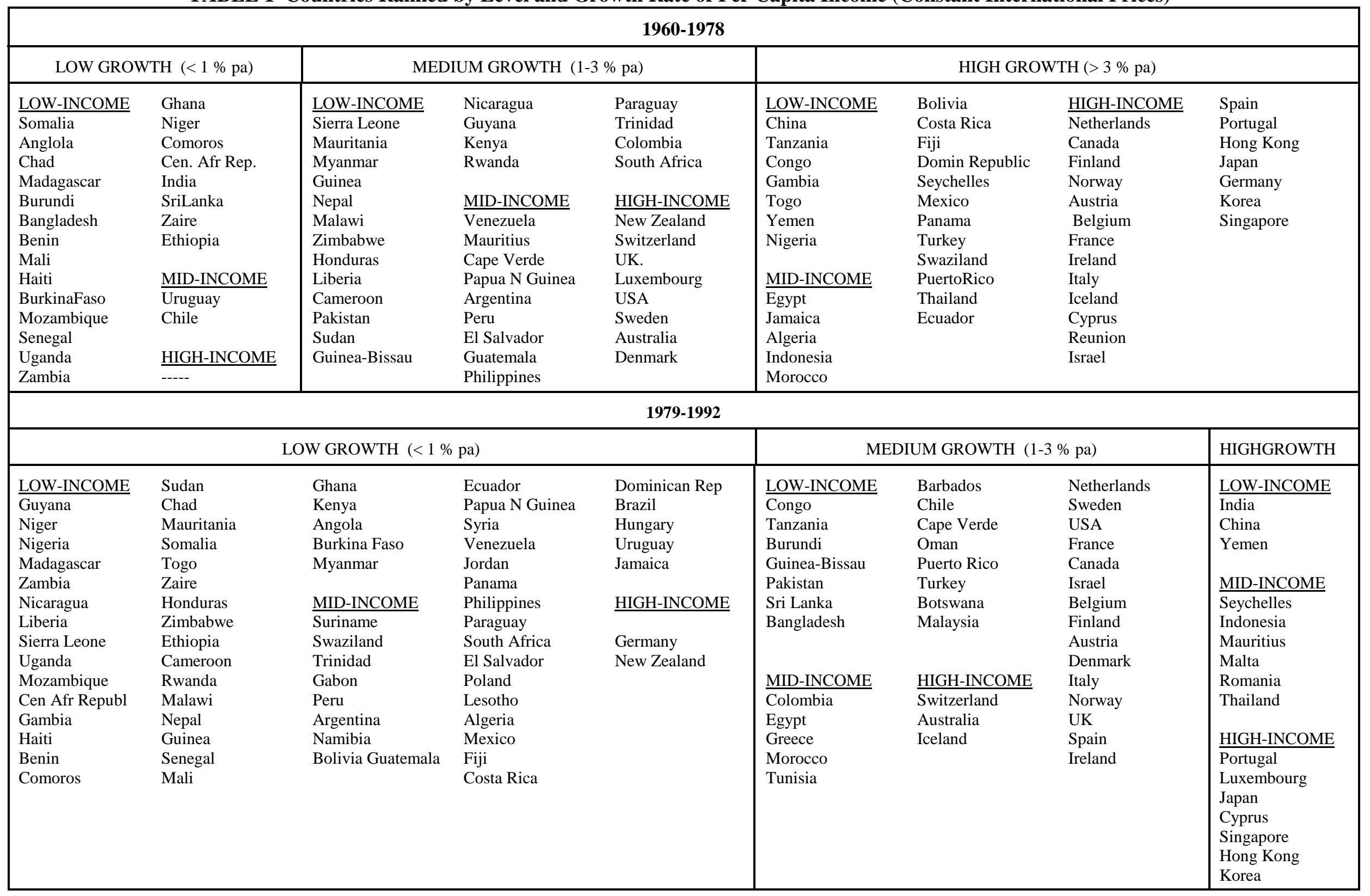


Table 2: The Relation between Income Growth and Initial Income (1960-1992)

(trend growth rate of yIP-85 regressed on the log of initial yIP-85)

\begin{tabular}{|c|c|c|c|c|c|c|c|c|c|}
\hline & \multicolumn{3}{|c|}{$1960-78$} & \multicolumn{3}{|c|}{$1979-92$} & \multicolumn{3}{|c|}{$1960-92$} \\
\hline & Constant & Initial yIP-85 & Adj. R2 & $\underline{\text { Constant }}$ & $\underline{\text { Initial yIP-85 }}$ & Adj. R2 & Constant & $\underline{\text { Initial yIP-85 }}$ & Adj. R2 \\
\hline Low Income & $\begin{array}{c}8.478 * * \\
{[4.092]}\end{array}$ & $\begin{array}{c}-1.098 * * * \\
{[0.622]}\end{array}$ & 0.045 & $\begin{array}{c}-0.752 \\
{[4.649]}\end{array}$ & $\begin{array}{c}6.6 \mathrm{E}-02 \\
{[0.683]}\end{array}$ & -0.023 & $\begin{array}{l}9.562 * \\
{[3.398]}\end{array}$ & $\begin{array}{c}-1.370 * * \\
{[0.516]}\end{array}$ & 0.118 \\
\hline Middle Income & $\begin{array}{l}9.304 * \\
{[3.158]}\end{array}$ & $\begin{array}{c}-0.742 * * * \\
{[0.423]}\end{array}$ & 0.064 & $\begin{array}{l}9.616 * * \\
{[4.605]}\end{array}$ & $\begin{array}{c}-1.141 * * \\
{[0.569]}\end{array}$ & 0.062 & $\begin{array}{l}12.777 * \\
{[2.228]}\end{array}$ & $\begin{array}{l}-1.389^{*} \\
{[0.299]}\end{array}$ & 0.310 \\
\hline High Income & $\begin{array}{c}21.717 * \\
{[3.123]}\end{array}$ & $\begin{array}{l}-2.078 * \\
{[0.370]}\end{array}$ & 0.549 & $\begin{array}{c}22.116^{*} \\
{[5.284]}\end{array}$ & $\begin{array}{l}-2.146^{*} \\
{[0.577]}\end{array}$ & 0.322 & $\begin{array}{c}20.155^{*} \\
{[2.141]}\end{array}$ & $\begin{array}{l}-2.001 * \\
{[0.253]}\end{array}$ & 0.694 \\
\hline All Countries & $\begin{array}{c}-1.104 \\
{[1.600]}\end{array}$ & $\begin{array}{l}0.556^{*} \\
{[0.217]}\end{array}$ & 0.084 & $\begin{array}{c}-4.514 * \\
{[1.494]}\end{array}$ & $\begin{array}{l}0.649 * \\
{[0.189]}\end{array}$ & 0.081 & $\begin{array}{l}-0.362 \\
{[1.393]}\end{array}$ & $\begin{array}{c}0.315^{* * *} \\
{[0.189]}\end{array}$ & 0.014 \\
\hline
\end{tabular}

Note: 1. Standard errors in parentheses.

2. See appendix for variable definitions and data sources.

3. * denotes significant at $1 \%$ level.

** significant at $5 \%$ level

*** significant at $10 \%$ level 
Table 3: The Distribution of World Income (1960-89)

\begin{tabular}{|c|c|c|c|c|c|}
\hline \multirow[t]{2}{*}{ Year } & \multicolumn{2}{|c|}{ Gini Coefficients } & \multicolumn{2}{|c|}{$\begin{array}{c}\text { Ratio of Top } 20 \% \\
\text { to Bottom } 20 \%\end{array}$} & \multirow[t]{2}{*}{$\begin{array}{l}\text { P-level in Top } 20 \% \text { to } \\
\text { P-level in Bottom } 20 \%\end{array}$} \\
\hline & $\begin{array}{c}\mathrm{y}_{\mathrm{IP}-\text { curr }} \\
{[1]}\end{array}$ & $\begin{array}{c}\mathrm{y}_{\mathrm{NP}-\text { curr }} \\
{[2]}\end{array}$ & $\begin{array}{c}\mathrm{y}_{\mathrm{IP}-\text { curr }} \\
{[3]}\end{array}$ & $\begin{array}{c}\mathrm{y}_{\mathrm{NP}-\text { curr }} \\
{[4]}\end{array}$ & \\
\hline 1960 & 0.44 & $\mathrm{n} / \mathrm{a}$ & 11.10 & $\mathrm{n} / \mathrm{a}$ & -- \\
\hline 1970 & 0.50 & 0.71 & 13.90 & 31.90 & 2.30 \\
\hline 1980 & 0.53 & 0.79 & 16.00 & 44.70 & 2.79 \\
\hline $1988-89$ & 0.55 & 0.85 & 17.10 & 54.50 & 3.19 \\
\hline
\end{tabular}

Source: Based on UNDP, cited in Griffin and Khan (1992)

Table 4: Exchange Rate Deviation Index (1960-1995)

\begin{tabular}{lcc}
\hline & $1960-78$ & $1979-95$ \\
\hline Low Income & 2.29 & 2.70 \\
& {$[1.36]$} & {$[3.95]$} \\
Middle Income & 1.92 & 1.97 \\
& {$[1.50]$} & {$[2.03]$} \\
High Income & 1.26 & 1.03 \\
& {$[1.00]$} & {$[0.88]$} \\
\hline
\end{tabular}

Note: 1. The ERD Index is the nominal/PPP exchange ratio (which equals the ratio of GDP at international prices to GDP at national prices).

2. Figures in parentheses are GDP-weighted means; all other figures are unweighted country means. 
Table 5: The Relation between the Exchange Rate Deviation Index and Income (1960-1995)

(ERD index regressed on the log of yNP-87, pooled sample)

\begin{tabular}{|c|c|c|c|c|c|c|c|c|c|}
\hline & & $1960-78$ & & & $1979-95$ & & & $1960-95$ & \\
\hline & $\underline{\text { Constant }}$ & yNP-87 & $\underline{\text { Adj. R2 }}$ & $\underline{\text { Constant }}$ & yNP-87 & Adj. R2 & $\underline{\text { Constant }}$ & yNP-87 & Adj. R2 \\
\hline Low Income & $\begin{array}{l}5.651^{*} \\
{[0.460]}\end{array}$ & $\begin{array}{c}-0.574 * \\
{[0.079]}\end{array}$ & 0.126 & $\begin{array}{l}9.658^{*} \\
{[0.602]}\end{array}$ & $\begin{array}{l}-1.186^{*} \\
{[0.103]}\end{array}$ & 0.197 & $\begin{array}{c}-4.8 \mathrm{E}-06^{* *} \\
{[0.000]}\end{array}$ & $\begin{array}{c}1.0 \mathrm{E}-06^{* *} \\
{[0.000]}\end{array}$ & 0.009 \\
\hline Middle Income & $\begin{array}{c}-55.610 \\
{[46.911]}\end{array}$ & $\begin{array}{c}9.841 \\
{[6.698]}\end{array}$ & 0.002 & $\begin{array}{l}6.191^{*} \\
{[0.263]}\end{array}$ & $\begin{array}{c}-0.577^{*} \\
{[0.036]}\end{array}$ & 0.307 & $\begin{array}{c}-20.565 \\
{[26.989]}\end{array}$ & $\begin{array}{c}3.996 \\
{[3.771]}\end{array}$ & 0.000 \\
\hline High Income & $\begin{array}{l}4.515^{*} \\
{[0.154]}\end{array}$ & $\begin{array}{c}-0.366^{*} \\
{[0.017]}\end{array}$ & 0.479 & $\begin{array}{l}4.894 * \\
{[0.176]}\end{array}$ & $\begin{array}{l}-0.410^{*} \\
{[0.019]}\end{array}$ & 0.572 & $\begin{array}{l}4.697 * \\
{[0.110]}\end{array}$ & $\begin{array}{l}-0.387^{*} \\
{[0.012]}\end{array}$ & 0.549 \\
\hline All Countries & $\begin{array}{c}0.859 \\
{[10.402]}\end{array}$ & $\begin{array}{c}0.733 \\
{[1.449]}\end{array}$ & 0.000 & $\begin{array}{l}5.837 * \\
{[0.123]}\end{array}$ & $\begin{array}{c}-0.523 * \\
{[0.017]}\end{array}$ & 0.392 & $\begin{array}{c}4.009 \\
{[5.729]}\end{array}$ & $\begin{array}{c}0.032 \\
{[0.786]}\end{array}$ & 0.000 \\
\hline
\end{tabular}

Note: 1. Standard errors in parentheses.

2. See appendix for variable definitions and data sources.

3 . * denotes significant at $1 \%$ level.

** denotes significant at 5\% level 
Table 6: The International Distribution of Capital Flows (1995)

(\% of World Total)

\begin{tabular}{|c|c|c|c|c|c|}
\hline \multicolumn{2}{|c|}{ Low Income } & \multicolumn{2}{|c|}{ Middle Income } & \multicolumn{2}{|c|}{ High Income } \\
\hline China & 12.7 & Brazil & 4.7 & USA & 21.3 \\
\hline Nigeria & 2.9 & Hungary & 2.5 & Italy & 12.4 \\
\hline \multirow[t]{7}{*}{ India } & 1.6 & Argentina & 2.2 & Spain & 8.6 \\
\hline & & Thailand & 1.9 & Canada & 5.3 \\
\hline & & Poland & 1.8 & Austria & 3.6 \\
\hline & & Indonesia & 1.4 & Korea, Rep & 3.3 \\
\hline & & & & Denmark & 2.8 \\
\hline & & & & Australia & 1.7 \\
\hline & & & & Sweden & 1.0 \\
\hline$\underline{\text { Total }}$ & 17.9 & & 19.9 & & 62.2 \\
\hline
\end{tabular}

Note: Only recipients with net receipts exceeding $1 \%$ of the world total are included.

Table 7: Capital Flows Relative to Gross Domestic Investment (1995)

(\% of National Gross Domestic Investment)

\begin{tabular}{llllll}
\hline \multicolumn{2}{c}{ Low Income } & \multicolumn{2}{c}{ Middle Income } & \multicolumn{2}{c}{ High Income } \\
\hline \multirow{2}{*}{ Nigeria } & 64.3 & Hungary & 67.1 & Denmark & 28.7 \\
Nicaragua & 20.6 & Namibia & 25.4 & Spain & 19.5 \\
Pakistan & 13.9 & Poland & 23.9 & Italy & 16.9 \\
Tanzania & 12.4 & Mauritius & 19.2 & Austria & 15.7 \\
China & 12.3 & Uruguay & 16.4 & Ireland & 15.6 \\
Gambia & 10.3 & Costa Rica & 16.0 & N Zealand & 13.7 \\
& & Jordan & 14.7 & Canda & 13.4 \\
& & Colombia & 14.1 & Israel & 10.7 \\
& & Philippines & 13.6 & & \\
& & Dom. Rep. & 12.4 & & \\
& & Papua N.Gui & 12.4 & & \\
& & Argentina & 11.4 & & \\
& & Paraguay & 11.3 & & \\
& & & & & \\
& & & & & \\
& & &
\end{tabular}

Note: Only recipients with inflows exceeding $10 \%$ of gross domestic investment are incli 
Table 8: Saving and Investment Rates (1960-1995)

(\% of Gross Domestic Product)

\begin{tabular}{lcc}
\hline & $1960-78$ & $1979-95$ \\
\hline Low Income & & \\
Sav. Rate (NP) & 12.7 & 23.1 \\
Inv. Rate (NP) & 18.9 & 16.2 \\
Inv. Rate (IP) & 15.0 & 8.2 \\
& & \\
Middle Income & & \\
Sav. Rate (NP) & 24.7 & 21.2 \\
Inv. Rate (NP) & 24.0 & 24.1 \\
Inv. Rate (IP) & 20.9 & 17.4 \\
& & \\
High Income & & 24.8 \\
Sav. Rate (NP) & 29.4 & 23.7 \\
Inv. Rate (NP) & 29.4 & 28.1 \\
Inv. Rate (IP) & 29.6 & \\
& & 27.6 \\
All Countries & & 22.4 \\
Sav. Rate (NP) & 30.6 & \\
Inv. Rate (NP) & 27.8 & \\
Inv. Rate (IP) & 23.5 & \\
& & \\
\hline
\end{tabular}

Note: 1. NP denotes current national prices and IP current international prices.

2. The IP-investment rates refer to the period 1960-92 only.

3. All figures are GDP-weighted means, not unweighted country means. 
Table 9: Industry Share of Total GDP and Non-Service GDP (1960-1995)

(\%)

\begin{tabular}{|c|c|c|c|c|}
\hline & & 1960-78 & 1979-95 & 1960-95 \\
\hline \multirow[t]{2}{*}{ Low Income } & GDP & 20.6 & 18.5 & 19.4 \\
\hline & NS-GDP & 28.2 & 27.1 & 27.6 \\
\hline \multirow[t]{2}{*}{ Middle Income } & GDP & 29.2 & 28.2 & 28.9 \\
\hline & NS-GDP & 54.4 & 64.9 & 59.5 \\
\hline \multirow[t]{2}{*}{$\underline{\text { High Income }}$} & GDP & 35.4 & 31.9 & 33.5 \\
\hline & NS-GDP & 75.2 & 79.1 & 77.3 \\
\hline \multirow[t]{2}{*}{$\underline{\text { All Countries }}$} & GDP & 26.3 & 28.0 & 26.9 \\
\hline & NS-GDP & 49.0 & 55.9 & 52.5 \\
\hline
\end{tabular}

Note: All figures are unweighted country means.

Table 10: Openness to Commodity Trade (1960-1992)

(Exports+Imports as \% of Gross Domestic Product)

\begin{tabular}{lccc}
\hline & $1960-78$ & $1979-92$ & $1960-92$ \\
\hline$\underline{\text { Low Income }}$ & & & \\
& 48.2 & 54.5 & 52.1 \\
& {$[18.0]$} & {$[25.6]$} & {$[23.9]$} \\
$\underline{\text { Middle Income }}$ & & & \\
& 61.1 & 72.0 & 65.5 \\
$\underline{\text { High Income }}$ & {$[34.2]$} & {$[41.0]$} & {$[38.1]$} \\
& 70.4 & & \\
& {$[37.0]$} & 89.1 & 78.3 \\
All Countries & 58.6 & $748.8]$ & {$[44.6]$} \\
& {$[33.8]$} & {$[45.8]$} & 63.5 \\
\hline
\end{tabular}

Note: Figures in parentheses are GDP-weighted means; all other figures are unweighted country means. 
Table 11: Share of Manufactures in Merchandise Exports (1965-1992)

$(\%)$

\begin{tabular}{lccc}
\hline & 1965 & 1979 & 1992 \\
\hline$\underline{\text { Low Income }}$ & & & \\
& 11.7 & 17.8 & 34.5 \\
& {$[15.0]$} & {$[45.7]$} & {$[80.0]$} \\
$\underline{\text { Middle Income }}$ & 17.3 & & \\
& {$[16.3]$} & 40.5 & 62.9 \\
$\underline{\text { High Income }}$ & 55.2 & {$[44.7]$} & {$[70.9]$} \\
& {$[72.5]$} & 73.6 & 83.3 \\
$\underline{\text { All Countries }}$ & 25.6 & {$[80.3]$} & {$[87.0]$} \\
& {$[62.5]$} & 47.1 & 64.5 \\
& & {$[75.7]$} & {$[84.2]$} \\
\hline
\end{tabular}

Note: Figures in parentheses are GDP-weighted means; all other figures are unweighted country means.

$\underline{\text { Table 12: Population Living on Less than } \$ 1 \text { per Day }(1987,1993)}$

\begin{tabular}{lcccc}
\hline & $\begin{array}{c}1987 \\
\text { Population (millions) }\end{array}$ & $\begin{array}{c}1987 \\
\text { Share of Population (\%) }\end{array}$ \\
E. Asia + Pacific & 464 & 446 & 28.8 & 26.0 \\
Europe + Cent. Asia & 2 & 15 & 0.6 & 3.5 \\
Latin Am. + the Carrib. & 91 & 110 & 22.0 & 23.5 \\
Mid. East + N. Africa & 10 & 11 & 4.7 & 4.1 \\
South Asia & 480 & 515 & 45.4 & 43.1 \\
Sub-Saharan Africa & 180 & 219 & 38.5 & 39.1 \\
Total & 1227 & 1314 & 30.1 & 29.4 \\
& & & & \\
\hline
\end{tabular}

Note: Population below $\$ 1$ per day is the percentage of the population living on less than $\$ 1$ per day at 1985 international prices, adjusted for purchasing power parity. 
Table 13: The Distribution of National Incomes (1960-1995)

(Income Share of Top 20\% to Bottom 40\%)

\begin{tabular}{lccc}
\hline & $1960-78$ & $1979-95$ & $1960-95$ \\
$\underline{\text { Low Income }}$ & 3.94 & 2.99 & 3.57 \\
$\underline{\text { Middle Income }}$ & 4.77 & 4.1 & 4.4 \\
High Income & 2.63 & 2.16 & 2.5
\end{tabular}


APPENDIX: Sources of Data and Variable Definitions

1. World Bank, 1994, World Data, 1994.

2. World Bank, 1997, World Indicators, 1997.

The above sources were combined as necessary to get the country-wise annual time series data (1960-95) on all national accounts variables involving national price valuations. In addition, these are also the sources for capital flows, poverty incidence data (population living on less than $\$ 1$ per day) and the measures of inequality of national income.

$\mathrm{y}_{\mathrm{NP}-87}$ - per capita GDP at constant 1987 national prices (in US\$).

$\mathrm{y}_{\mathrm{NP}-\text { curr }}-$ per capita GDP at current national prices (in US\$).

3. International Comparisons Project, 1995, Penn World Table

The PennTable is the source for country-wise annual time series data (1960-1992) on all variables involving valuations at International Prices including the measure of trade openness.

$\mathrm{y}_{\mathrm{IP}-85}$ - per capita GDP at constant 1985 international prices, chain index (in US\$).

$\mathrm{y}_{\mathrm{IP}-\text { curr }}$ - per capita GDP at current international prices (in US\$).

3. International Labor Organization, 1997: source for labor force statstics used in computing productivitiy measures. 